\title{
Administrative structures in Germany
}

\section{Administration after 1945}

To some extent the Allies, especially the British, ${ }^{1}$ tried after the war to break older administrative traditions in Germany, but the Americans and French looked for guidance at the pre-Nazi administrative structures in their occupation zones. Nineteenth-century organizational structures were largely reinstated under the formula, "a new beginning, but not a fundamentally new organization." 2 But there was a focus on localizing administration, in part as a consequence of the Potsdam Agreement that called for "decentralization" in post-war Germany. ${ }^{3}$ The reconstruction of administration from the bottom up helped strengthen and stabilize local self-government. ${ }^{4}$ In the nineteenth century it was said that "the state ends with the Landrat [county administrator]." ${ }^{5}$ After May 1945 one could say that in the Western zones of Germany "the state only just begins with the Landrat."6

The Germans carried out wide-ranging territorial reorganizations and administrative reforms in the late 1960 s and $1970 \mathrm{~s},{ }^{7}$ but these efforts were not conceived as a deep-seated political change comparable to the administrative transformations in Prussia after 1870. Rather, they took the form of adjustments of the administrative organization to long-ignored changes in social and economic developments. ${ }^{8}$

Today the sixteen Länder are divided between thirteen territorial states (Flächenstaaten) and three city states (by size of population: Berlin, Hamburg, and Bremen). There are four large territorial states (by size of population: North-Rhine Westphalia, Bavaria, Baden-Württemberg, and Lower Saxony), eight medium-sized states, and one small territorial state (the Saarland). There is a remarkable unity in the basic structure of most of the territorial Länder; the most obvious difference lies in the lack of a 
"middle instance" in six small-to-medium Länder. The city states are different in principle, because they make no distinction between "state" and "local" administration (with some modifications regarding Bremen and Bremerhaven). ${ }^{9}$

\section{Some principles and concepts}

Although Article 83 of the Basic Law speaks only of the Länder executing federal laws on their own responsibility, there is a constitutional presumption that there are three administrative arenas in the Federal Republic: federal, Land, and local. While there are various interconnections among these arenas, they remain more or less separate and autonomous. Nevertheless, Articles 30 and 83 make reference only to the federation and the Länder, ${ }^{10}$ and the basic constitutional structure, as in the United States, consists of these two levels. ${ }^{11}$ Unlike the United States, however, where the local governments are not even mentioned in the Constitution and are creatures of the states, counties and municipalities are singled out for protection by Article 28 of the Basic Law. This protection does not extend to individual local governments but rather to the institution of the county and the municipality. Their organizational structure and boundaries are matters for the Länder to determine. As constituent parts of the Länder, the local governments are also responsible for administration and, therefore, they execute federal as well as Land laws along with their own ordinances. ${ }^{12}$

In the discussion of levels of administration below, several distinctions should be kept in mind. One is between direct administration, which is generally the "own" administration (Bundeseigene, Landeseigene Verwaltung) by state agencies discussed above in Chapter 2 on the constitutional framework - for example, the federal crime office or air controllers; and indirect administration, which includes the "delegated" administration - for example, federal highway administration delegated to the Länder or the federal health insurance program delegated to regional sickness funds. At the Land level, there is direct Land administration of the schools and police and indirect administration of a large majority of "state" (federal and Land) laws mostly by the semiautonomous counties and cities but also by numerous non-governmental institutions. Another distinction is between general administration, exemplified best by the mid-level government districts and German rural counties and large county-free cities versus specialized administration by a wide variety of special authorities (Sonderbehörden). 


\section{Federal administration}

Federal administration differs significantly from Land administration in two ways: the federation has no general administrative agencies, only specialized agencies; and, with some exceptions discussed below, the federation has only high authorities with no substructures. ${ }^{13}$ As at the Land level, a distinction is made between the supreme authorities (oberste Behörden) and the high authorities (Bundesoberbehörden). A distinction is also made between direct and indirect administration.

Federal supreme authorities include the Chancellor and his office, the federal ministers, the Federal Accounting Office, and the Bundesbank. ${ }^{14}$ The federal president, the presidium of the Bundestag and Bundesrat, and the Federal Constitutional Court are sometimes given also as examples of supreme federal authorities, ${ }^{15}$ but they are not parts of the state administrative organization. ${ }^{16}$

The high federal special authorities answer to the federal ministries, i.e., to the supreme authorities from which they emerged as semiautonomous agencies. They generally have no substructures, but they can set up branches. Examples of high federal authorities are the Press and Information Office of the federal government, the Federal Statistical Office, the Federal Crime Office, the Federal Cartel Office, the Patent Office, the Office for Constitutional Protection, and the Federal Environmental Office. ${ }^{17}$ Other examples of direct federal administration are technical and research institutions (Bundesanstalten) that answer to the ministries, for instance, the air controllers under the Ministry of Transportation, ${ }^{18}$ or the Federal Insurance Office under the Ministries of Labor and Health that supervises the hundreds of public corporations that provide retirement, health, accident, and nursing care insurance in conformity with federal law. ${ }^{19}$

Subnational direct federal administrative structures exist only in the foreign service; federal waterways administration, which falls under the Ministry of Transportation and is organized at the middle as well as at lower levels; ${ }^{20}$ military and border control administration; and finance administration (see below). The federal railways and postal services had multiple levels until they were privatized in $1993-94 ;{ }^{21}$ however, the federal government still has certain supervisory and other responsibilities. ${ }^{22}$ The twenty-two high finance authorities (Oberfinanzdirektionen) are mid-level agencies that are a peculiar example of joint federal-Land administration, i.e., they serve simultaneously as agencies of the Länder. The head of such an office is both a federal and Land civil servant who directs both federal and Land sections. Lower- level agencies that answer 
to the high finance authorities include federal customs offices, federal property offices, and federal forest offices. As one can see from figure 3.1, the Länder also have their own finance offices that answer to the high finance authority. ${ }^{23}$

While less common, indirect administration also exists at the federal level. There is, for example, the Federal Employment Office in Nuremberg which has its own lower Land- and local- level structures. There is also the Deutsche Welle, which provides radio and television broadcasts for foreign listeners and viewers, while Deutschlandfunk, now Deutschlandradio, serves the domestic audience based on a contract with the Länder. The Bundesbank is also an example of indirect federal administration, but it is completely autonomous, as are its branches in the Länder (Landeszentralbanken). ${ }^{24} \mathrm{~A}$ variety of social insurance agencies are also included in indirect federal administration.

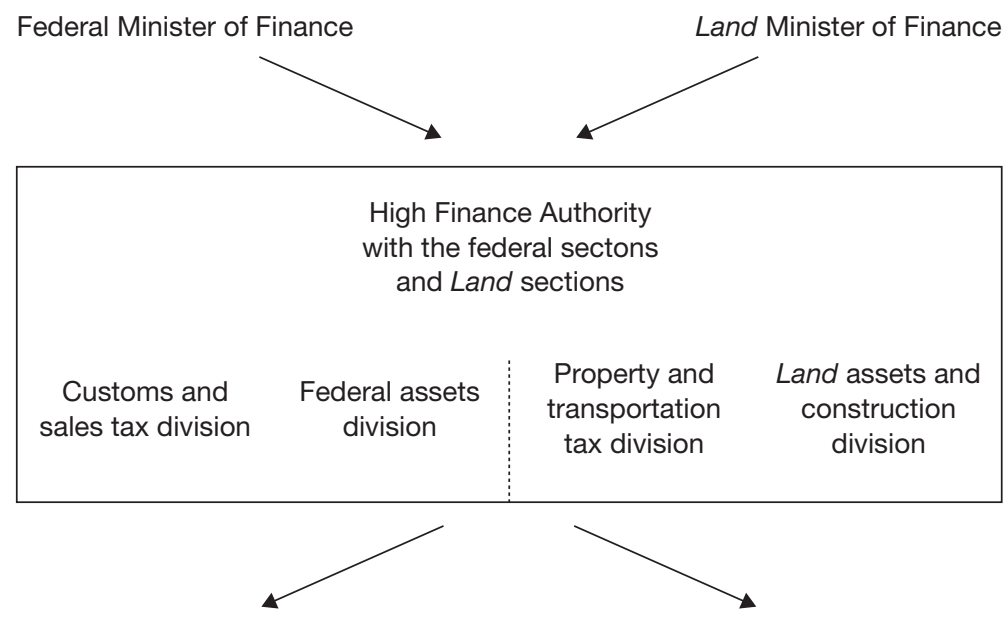

Major customs offices

Finance offices

Figure 3.1 The joint high finance authority

Administration in the territorial Länder and the city-states

The Länder are responsible for their own administrative organization. Some Länder provide for their organizational structure in a single law, others have it contained in several laws. In spite of a number of differences, there are certain common principles of organization based on 
general and special administrative agencies organized at three levels: the Land government (cabinet) or ministry level; the government district (Regierungsbezirk); and the rural county and city-county (or county-free city). Exceptions to the common principles are the three city-states and the Saarland, Schleswig-Holstein, Rhineland-Palatinate, Brandenburg, Mecklenburg-Vorpommern, and Thuringia (which has a Land Administrative Office as a substitute), all small-to-medium sized Länder that do not have the middle-level Regierungsbezirk. ${ }^{25}$

Administration in the federation and the Länder is separate in principle. Land administration is not under the federation but rather is an autonomous arena next to the federation. ${ }^{26}$ "Mixed administration" is supposedly not permitted by the Basic Law, for example, in that a Land agency reports to a federal agency or that the federation must approve Land measures or exercise some power of co-decision. In fact there are numerous examples of some form of mixed administration, ${ }^{27}$ although these depend in part on what is meant by the term. ${ }^{28}$ Examples of federal involvement in Land administration are the federal legal supervision of laws delegated to the Länder for administration and the joint tasks under Articles 91a and 91b described later in this chapter and in Chapter 2 on the constitutional framework of German federalism. An example of a joint agency is finance administration mentioned briefly above. The federation and the Länder have their own finance administration, but the twenty-two high finance authorities serve as joint agencies at the middle level of Land administration. Joint agencies also exist among the Länder. For example, the Film Assessment Office in Wiesbaden determines which movies should receive public subsidies based on a contract among the Land ministers of education and culture. Finally, there are coordinating agencies among the Länder, for example, the Conference of Education and Culture Ministers (Kultusministerkonferenz [KMK]); the Conference of Ministers of Justice; and the University Rectors Conference. ${ }^{29}$

\section{The three levels of Land administration}

The high level

The first of the three levels is called the high or central level (Oberstufe) which, as in the case of the federation above, consists of two parts: the supreme Land authorities (oberste Landesbehörden) and the high Land authorities (Landesoberbehörden). The supreme Land authorities are the Land government (cabinet), the prime minister (Ministerpräsident), and the cabinet ministers. Some would add the speaker of the Land parliament 


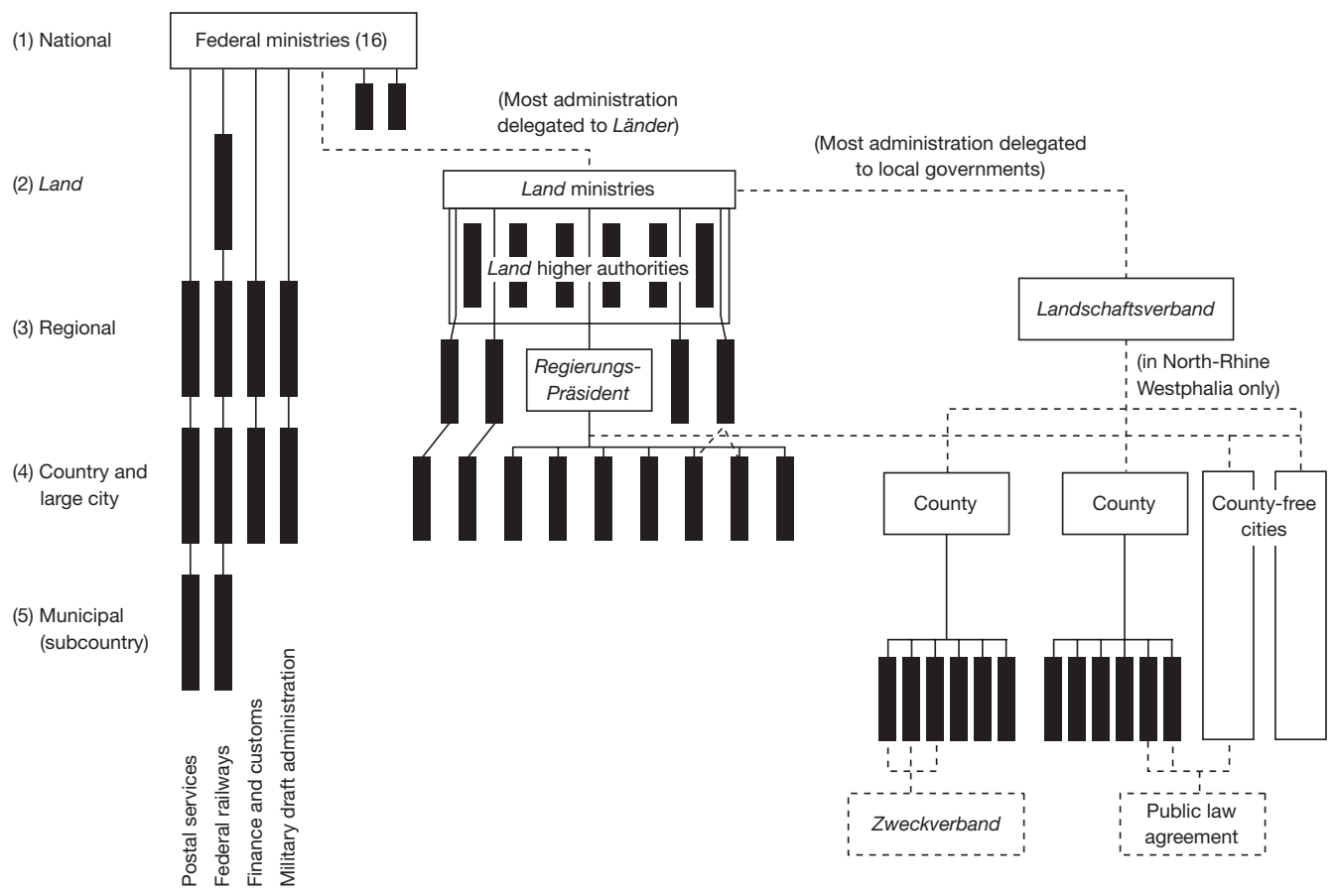

Figure 3.2 Structure of administration in the Federal Republic of Germany

Source: Adapted from Frido Wagener, "Äusserer Aufbau von Staat und Verwaltung," in Öffentliche Verwaltung in der Bundesrepublik Deutschland, edited by Klaus König, H. J. von Oertzen, and Frido Wagener (Baden-Baden: Nomos Verlagsgesellschaft, 1981), p. 80. 
and the Land accounting office. ${ }^{30}$ Unity is maintained by the guideline authority (Richtlinienkompetenz) of the prime minister and the principle of collegiality in the cabinet.

As indicated above, the prime minister is more than first among equals in the cabinet; he exercises the "guideline authority" or leadership of the government. Thus, in spite of the strong traditions of responsibility of ministers for their subject areas (Ressortprinzip) and collegiality, the prime minister is the boss (Kanzlerprinzip); but this is less true in the city-states. The prime minister represents the Land's interests vis-à-vis the other Länder in the prime ministers' conference and the federation in the Bundesrat, where he or she can exercise considerable influence on federal legislation. In this regard he is far more influential nationally than a typical American governor. He or she is assisted in leadership responsibilities by a staff (Staatskanzlei) responsible to the prime minister; in Baden-Württemberg, the staff is called Staatsministerium, in the city-states, Senatskanzleien. The prime minister's political staff has grown over the years along with the increasing role of the prime minister as dominant Land politician and Landesvater or "Land prince," a designation that reflects the prime minister's additional role as ceremonial head of state. ${ }^{31}$ The staff's first and permanent task is to coordinate the work of the ministers, to support the prime minister, to manage information, and to be innovative in initiating and conceptualizing policy proposals. Coordinating Land policy in the committees and plenary sessions of the Bundesrat is also a major activity. ${ }^{32}$ In addition, the chiefs of staff organize the meetings of Land prime ministers, which take place about every three months (about every six months with the Federal Chancellor). For a while, especially in the late 1960s and early 1970s, the prime minister's staff was engaged in development planning activities, but these have since been turned over to the ministries. ${ }^{33}$ On the other hand, political planning remains an important staff activity. ${ }^{34}$

As a rule the prime minister's staff is organized into offices that are responsible for areas such as parties and organizations; local governments; information and analyses; and preparation of legislation, speech writing, and setting the prime minister's calendar. The organization of the staffs in the city-states is considerably more modest, but press and public information offices are found everywhere. Some staffs house the office of the Land representative in Bonn (now Berlin), who usually also is head of the Land mission in the capital. Some staffs also have a special representative for European, i.e., EU, affairs. ${ }^{35}$

In most Länder there are from seven to nine ministries. These include the six core ministries (Interior, Education and Culture (Kultus), Finance, 
Economics, Social, and Justice) and others that have been added and eliminated over the years. For example, since the 1970s a Ministry of Science that has been given responsibility for the universities has been carved out of the older Ministry of Education and Culture ${ }^{36}$

The specific tasks of the ministries vary from Land to Land. Thus transportation is located in the Ministry of Interior in Baden-Württemberg but in the Ministry of Economics elsewhere. Sports may be in the ministries of education, interior, or social welfare. Variation is especially great regarding land use and environment, since it can be problematic to place environment and agriculture in one ministry. The most important ministry traditionally has been the Ministry of Interior, which has been a kind of "umbrella agency" for tasks not assigned to more specialized agencies. Therefore, it is the ministry with a certain unity of command function. ${ }^{37}$

Ministers are members of the government (cabinet) and heads of subject ministries. Thus they are responsible for central leadership and direction as well as for the personnel and functional supervision of lower-level authorities and institutions in their area. They develop general regulations and rules for administrative execution at lower levels and do Landwide planning. They draft legislation and regulations and deal with the Land parliament in areas under their responsibility. On the other hand, they make individual decisions only rarely. ${ }^{38}$

These activities lead to the dual function of the ministry serving as the highest administrative authority and at the same time as a political organ of the cabinet. This dual function is more apparent at the Land level than at the federal level, because the Land ministries have a complete subject area and an administrative structure to which they can give some unity and direction. This does not lead to a dualism between politics and administration so much as to the function of gearshift (Umschaltfunktion) between politics and administration. Thus the Land ministries more than their federal counterparts are "simultaneously lawmaking and administrative ministries." That is, the experience and information gained from administrative practice can be taken into account in the program development and policy making process in the ministry. ${ }^{39}$

In actual practice the above distinction between the political and administrative functions is difficult to make, because of the growth of Land ministries over the years resulting from demands on central direction and coordination activities. Growth in the ministries is also due to an increasing interaction with the Land parliaments in the number of written and oral questions raised and the close contact with parliamentary committees and with governing party group committees. Ministries have 
also borne the burden of an increasing tendency toward a concern with sets of single issues, such as the construction of an autobahn or federal highway, airport, or nuclear power plant. This gets ministries very much involved in planning activities which, in turn, tend to become politicized. In practice, then, it is difficult to develop a clear picture of the multiple functions of the ministries. They are program development agencies, but they also exercise supervision and control over subordinate units. ${ }^{40}$

In contrast to the supreme Land authorities (oberste Landesbehörden), the high Land authorities (Landesoberbehörden) are, like their federal counterparts, specialized agencies responsible to a minister. They tend to be technically demanding offices with extensive information-gathering responsibilities and data analysis and research capabilities. Examples include Land statistical offices, Land crime offices, and Land offices of constitutional protection. ${ }^{41}$ They also include specialized agencies such as the Land geological office and offices for environmental protection, earth research, plant protection, agricultural development, and so forth. A completely unique high authority is the Land Administrative Office in Lower Saxony which combines ten formerly autonomous high authorities without any particular connecting principle ${ }^{42}$

\section{The middle level (Mittelstufe or Mittelinstanz)}

At this level one finds the director (Regierungspräsident) of the district government (Bezirksregierung) of the government district (Regierungsbezirk). This is where the important Continental administrative principle of unity of command (Einheit der Verwaltung) has been applied most clearly in the German administrative tradition. It is where "state" (federal and Land) policies are "bundled" for implementation and where the director (similar to the classic example of the French prefect) serves as a coordinator and mediator between the high and the low levels of administration. The director of the government district is a political appointee and the general representative of the Land government in the district, and he or she ensures that the goals of the government are realized in the district. This, of course, is a political function; however, the director is also a special counsel for the concerns of the region vis-à-vis the Land and federal governments. Thus he may see himself as an "honest broker" between the "state" and local governments, as a representative of the Land in the district and of his district to the Land. ${ }^{43}$

The director is responsible especially to the Land Minister of the Interior but also to the other ministers for the proper administration of their policies and laws. But as an agent of "bundling" and coordination, the 
director is the most important counterweight against an otherwise dominant tendency toward specialization. The director attempts to counter specialization through a variety of means, including co-signature, discussions with section chiefs, coordinating units and through his involvement in various planning activities. However, some observers argue that vertical relationships (in the United States, "picket-fence" federalism) are so strong today in the organization of the government district along ministerial lines and between groups of subject experts at different levels that horizontal coordination is more difficult than in the past. ${ }^{44}$

There is a strong tradition in German administration - and on the Continent in general - that holds that specialized agencies such as those at all levels of American administration, especially the ubiquitous special districts at the local level, should be discouraged in principle if not always in fact. Where it is not feasible to integrate various functions in one administrative unit, there should be at least an attempt to have the function administered in one territory. ${ }^{45}$ This tradition today does not deny that there are some advantages to specialized administration, for example, administration by subject specialists, better performance by focusing on specific tasks, subject neutrality and nonpartisan implementation, and sometimes greater efficiency of administration. But disadvantages include "selective attention," narrowness of view and blindness to other factors, isolation within the general administrative structures, lack of coordination with other agencies, exaggeration of the importance of own area, and perfectionist tendencies among the administrators. This is reflected in the "vertical brotherhood of experts" 46 that exists between higher and lower levels in German administration. Special administrative agencies tend to be removed from politics; yet they are subject to capture by the clientèle they serve and special interest groups. They tend also to be less transparent, often less accountable, and removed from citizen input. ${ }^{47}$

The director of the government district has the function of guaranteeing the legal and uniform conduct of administration throughout the territory of the district through his functional and personnel supervision of subordinate state authorities. In some Länder (Bavaria, Lower Saxony, North-Rhine Westphalia) this includes the supervision of school teachers, who are Land civil servants. In other Länder, e.g., Baden-Württemberg, there is a separate and special hierarchical organization for schools. In a more general and traditional sense, the director provides legal supervision of local governments in their areas of autonomous self-government. This usually involves consultation and advice, but repressive measures are 
available to the director in extreme cases. Related to this function is the review of grant applications by local governments. The director also provides legal supervision of other public corporations, such as schools. He is responsible for the legal and functional supervision of delegated state tasks carried out by local governments as well as by special authorities under the authority of the district government. ${ }^{48}$

While the government districts are in principle institutions of general administration, they also carry out specialized administration on behalf of the ministries. This relieves the ministries of certain administrative burdens that for certain reasons cannot be included in the area of responsibility of local governments. The number and kind of specialized functions performed by the district government, and/or supervised by it at the local branch level, varies among the Länder, but they tend to require special expertise or involve common standards. Examples include the administration of technically complicated emission controls, traffic planning, protection of nature areas, management of public property, regional planning, and planning and taking certain measures in the areas of water management and agriculture. ${ }^{49}$

In spite of the theory of unity of command and the efforts to combine as many tasks as possible in the district governments, counties and cities, there are special authorities at the middle level that can be found at least to some extent outside the confines of the district governments. Lower Saxony differs from the other Länder in that it has a Land Administrative Office at the high level that combines several functional agencies outside of the middle-level district governments but is not a "bundling" office..$^{50}$ Thuringia and Rhineland-Palatinate have also created Land administrative agencies that perform some of the functions found in the district governments in other Länder. Nevertheless, even in Lower Saxony there are special agencies that answer directly to the ministries and do not fall under the supervision of either the district governments or the Land Administrative Office. An unusual example of an activity that is not included in the government districts is finance administration, where the high finance office is both a federal and a Land middle-level agency directed by a head who is both a federal and Land official. Salaries and appointments of the public employees as well as functions are divided between the federal and Land officials. Below the middle-level agency are branch offices in the municipalities. The territory served by these local branches does not always conform with county boundaries. ${ }^{51}$

Following the territorial and administrative reforms of the 1960s and 1970s and the re-establishment of five new Länder in the East, there were 
thirty-two government districts which differed significantly in size of population and area. No other administrative institution has been called into question so often since 1945; the government districts were almost eliminated by Baden-Württemberg in the early 1970s. In the late 1990s they were being considered for elimination by Rhineland-Palatinate, and in 1999 a law was introduced in the Land parliament which did, indeed, replace the three government districts as of 1 January 2000 with "structure and licensing directions" in Koblenz and Neustadt/Weinstraße and a "supervisory and service center" in Trier. ${ }^{52}$ During the discussions regarding the territorial reforms of the late 1960s and early 1970s mentioned above, some critics argued that the functions of the district governments could be divided in part by the ministries and the counties, and, especially, that they could be replaced by integrated planning and administrative and financing agencies at the regional level. At least in the larger territorial Länder, in contrast to the Rhineland-Palatinate, the view prevailed that they were necessary, and regional planning today is in effect mostly planning by the government district but in some Länder by the counties. The government districts appear now to be firmly established in the larger Länder, ${ }^{53}$ however, as noted above, there is no middle level in six of the smaller territorial Länder: the Saarland; Schleswig-Holstein; Rhineland-Palatinate; Mecklenburg-Vorpommern; Brandenburg; and Thuringia, which has a substitute in the form of a Land administrative office. ${ }^{54}$ North-Rhine Westphalia, which is a large territorial state with the largest population, is in the process of reforming and reorganizing its government districts.

A nonpartisan administration in the government districts is assumed; however, given the politicization of much of the higher levels of administration in Land and local governments in recent decades, some concern has been expressed about the tradition of political neutrality at the middle level of administration. Certain voices have called for a district government that is "closer to the people," a more "democratized" or "parliamentarized" or less bureaucratized administration. But there is no reason why the middle level should be "political" just because the higher and lower levels are. Indeed, the difficult job of serving as a mediator and coordinator between Land and local governments, which often have different partisan colors, cannot be performed well by a partisan district government. ${ }^{55}$ Besides, any parliamentarization at the government district level would subtract proportionately from the authority of the Land parliaments and elected county and local government councils (figure 3.3). ${ }^{56}$ 


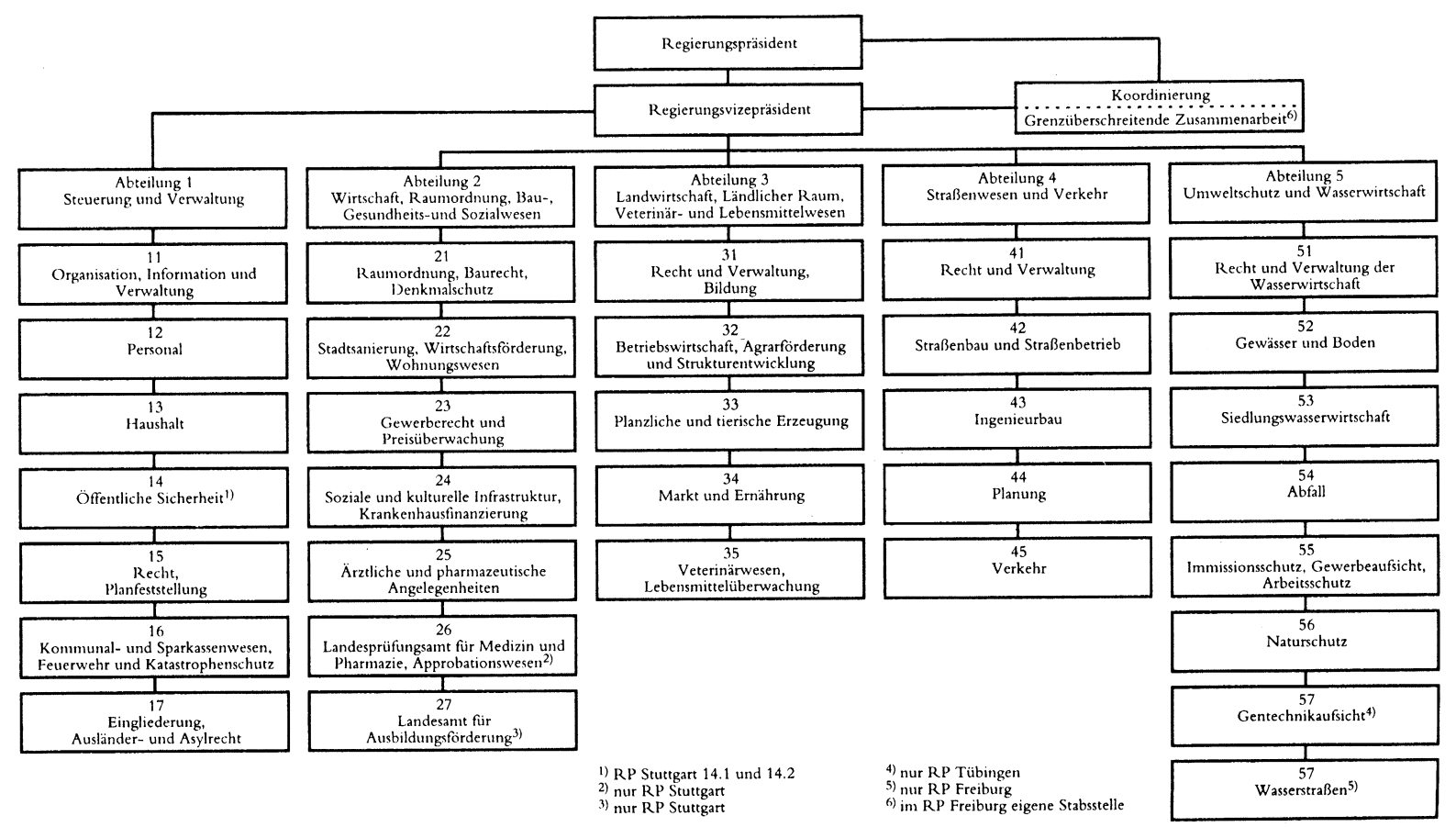

Figure 3.3 Organization plan for the government districts of Baden-Württemberg 
Lower Saxony was mentioned at the end of the previous section as having a unique high authority in the form of a Land Administrative Office in addition to government districts. Thüringia, in contrast, differs from all other Länder in having established a single Land Administrative Office at the middle level in place of government districts. The RhinelandPalatinate, as noted above, has just replaced its three government districts with three other regional offices.

\section{The lower level: direct state administration}

In all of the Länder there are varying numbers and kinds of offices that in some cases are directly responsible to high Land special authorities but mostly answer to the government districts (in the Länder with no government districts, some local state offices are directly responsible to the supreme Land authorities, i.e., the ministries). Typical examples of the former are weights and measures, autobahn, road construction, and finance offices. The far more numerous examples of state offices that are supervised by the government districts include the police, and land registry, agriculture, and business regulation offices, and in most, but not in all, cases, school administration and forestry (figures 3.4 and 3.5).

\section{The lower level: indirect administration by local governments}

Public administration on behalf of the state is also carried out by local governments. Indeed, it is estimated that $75-80$ percent of all federal and Land laws are implemented by local governments. The most important units in this regard are the counties, of which there are two kinds: the "rural county" (Landkreis), which may be in fact rather densely populated owing to the size and number of municipalities that constitute the county; and the "city-county" (Stadtkreis), ${ }^{57}$ a larger city usually referred to as the county-free city (kreisfreie Stadt).

The lower level: rural county government German rural counties are territorial public corporations consisting of municipalities, their surrounding territory, and their citizens (thus Gemeindeverband). There is very little unincorporated territory in Germany; examples would be certain forests and lakes. The counties' purpose is to administer those matters that are "above" or beyond the reach or capability of the municipalities that constitute the county. Matters of county self-government include the voluntary establishment and maintenance of social and cultural institutions 


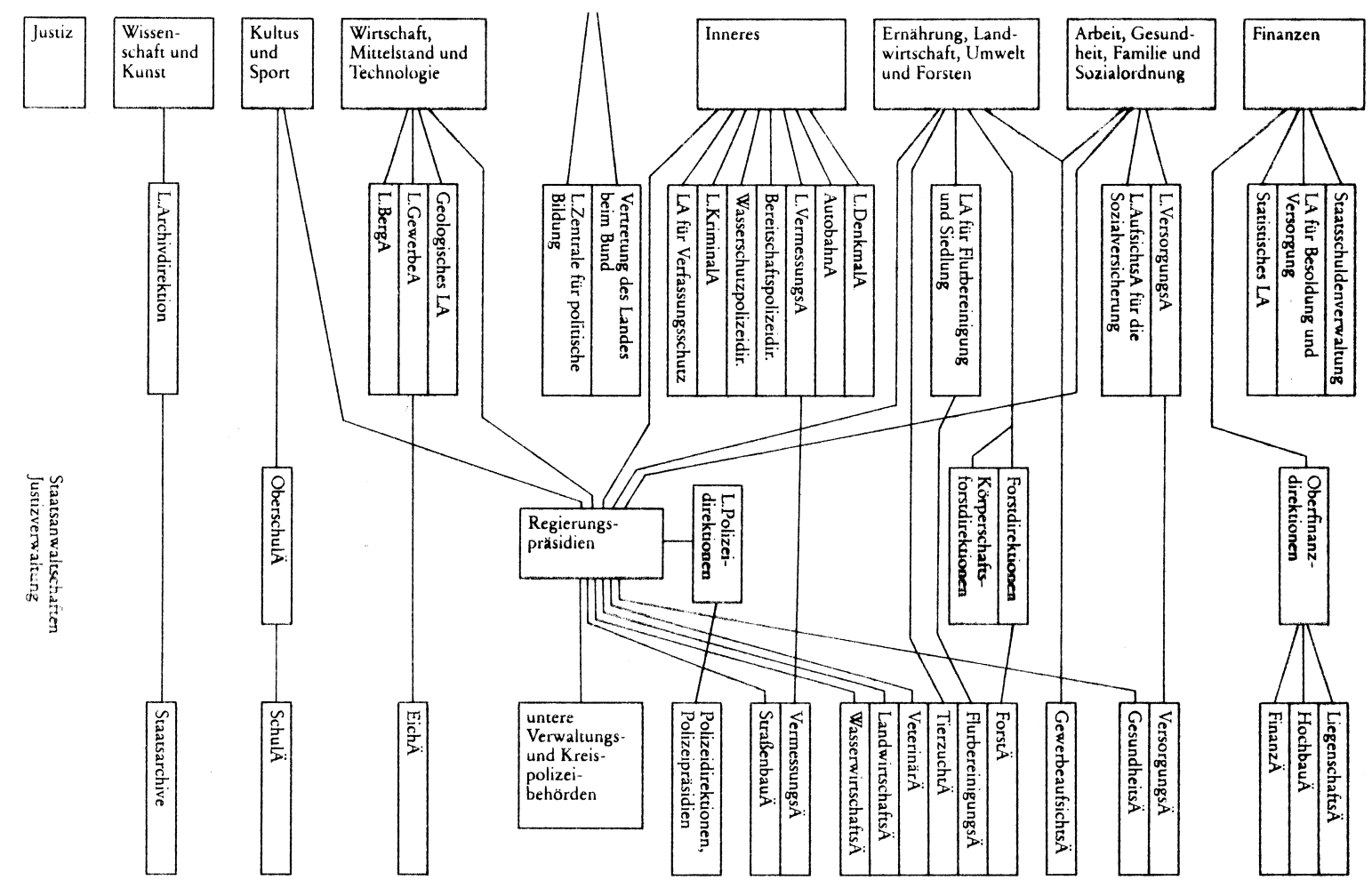

Figure 3.4 Organization plan of Baden-Württemberg

Source: Rainer Wahl, "Die Organisation und Enturicklung der Verwallung in den Ländern und in Berlin," in Deutsche Verwaltungsgeschichte, Band 5: Die Bundesrepublic Deutschland, edited by Kurt G. A. Jeserich et al. (Stuttgart: Deutsche Verlagsanstalt, 1987), p. 243. 


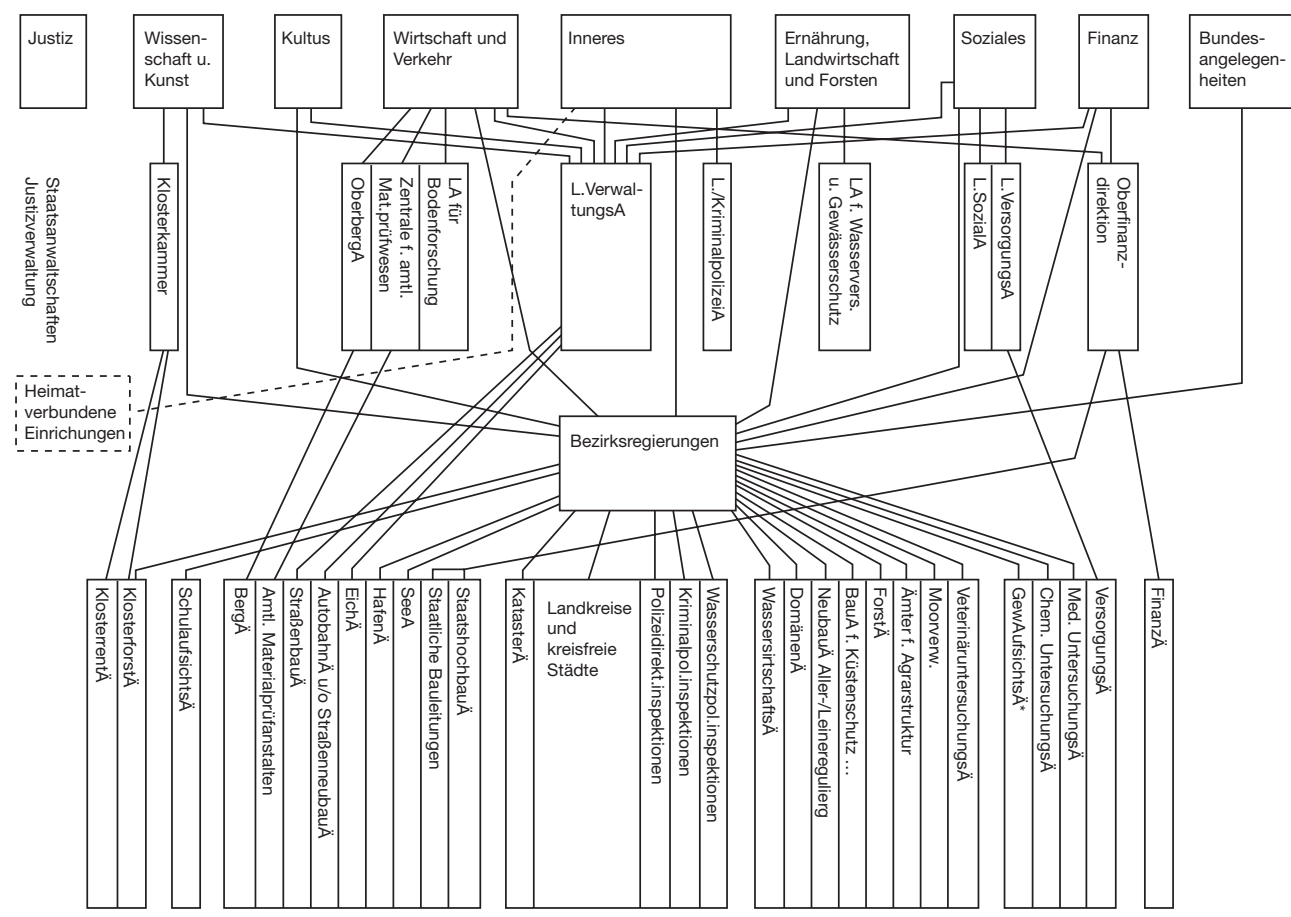

Figure 3.5 Organization plan of Lower Saxony

Source: Rainer Wahl, "Die Organisation und Enturicklung der Verwallung in den Ländern und in Berlin," in Deutsche Verwaltungsgeschichte, Band 5: Die Bundesrepublic Deutschland, edited by Kurt G. A. Jeserich et al. (Stuttgart: Deutsche Verlagsanstalt, 1987), p. 243. 
such as concert halls and museums; the construction and maintenance of general schools, retirement and nursing homes; hospitals and ambulance services, etc. Mandated tasks may include fire protection; vocational schools; county roads; waste disposal; and last-resort public assistance (Sozialhilfe). Delegated tasks include the administration of student subsidies for promoting education; rent subsidies (Wohngeld); health and veterinary offices; office for foreigners; building supervision; monument maintenance; dam supervision; and hunting and fishing licenses. The rural county can delegate some functions to its municipalities. ${ }^{58}$

The Landrat (until the second half of the 1990s a mostly ceremonial figure in North-Rhine Westphalia and Lower Saxony, see map 3.1) is the chief administrative officer responsible for the administration of both "state" and local affairs - that is, he combines the two at the rural county level and is the "connecting link between state administration and selfgovernment in the county." As such he falls under the legal and functional supervision of the government district. ${ }^{59}$ Germans therefore sometimes speak of the county's "loaning" the Landrat to the state (Land) for the

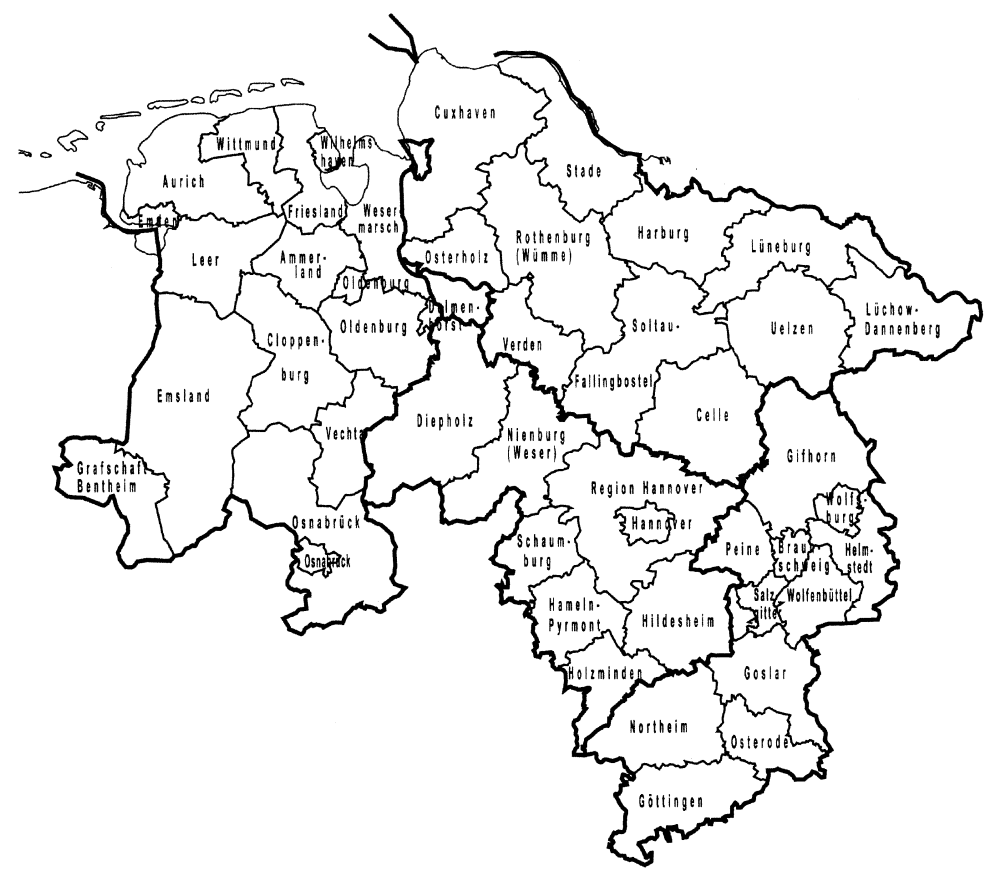

Map 3.1 Counties and county-free (independent) cities in Lower Saxony 
administration of state (both federal and Land) laws; ${ }^{60}$ however, in Lower Saxony the county government has been "communalized" as a result of the pressure of British occupation authorities after the war to remove the "state" from local government. Thus the county manager in Lower Saxony (now also called Landrat) performs delegated tasks on behalf of the Land, but as a local official..$^{61}$ In the other Länder the Landrat can be seen as an agent of direct state administration, even though he is a local government official. But there are no state administrative offices within the jurisdiction of the cities, towns, and villages that make up the county, so their administration of state laws is indirect administration under the legal supervision of the Landrat. Of course, the specific responsibilities of the Landrat vary rather significantly among the Länder.

The lower level: municipal governments The cities, towns, and villages (Gemeinden in German; communes in French) are territorial public corporations which have the right of self-government as guaranteed by Article 28, para. 2, sent. 1 of the Basic Law (see map 3.2). They are responsible for the entire range of public administration in their territory, which is in conformity with the principle of unity of command (Einheit der Verwaltung) that stands in sharp contrast to the functional fragmentation

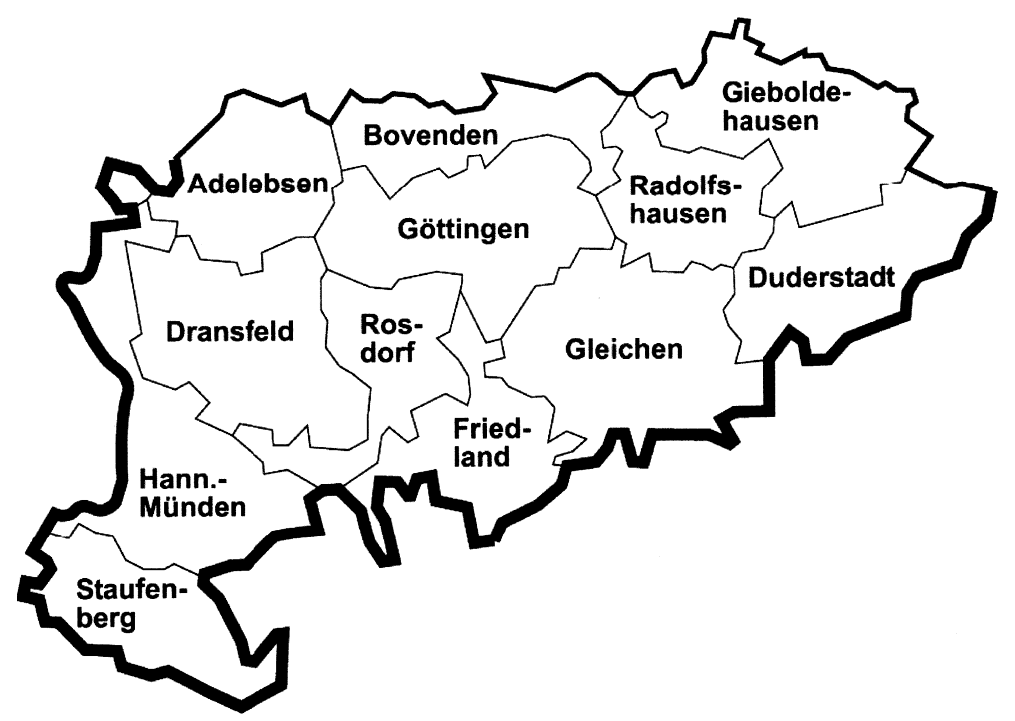

Map 3.2 The municipalities (Gemeinden) in the county of Göttingen 
of local government administration in the United States. They have different political and administrative structures, depending on the respective Land-wide charter law (Gemeindeordnung). ${ }^{62}$ There was a change in the Länder in the 1990s to direct election of the mayor as chief executive officer (even in the North German city manager systems), which has always been a feature of the South German Council form found in Baden-Württemberg and Bavaria. With its adoption by the five new Länder in the East, the South German Council form of local government is now the most common in Germany. ${ }^{63}$

German municipalities are responsible for two kinds of administration: matters of self-government (Selbstverwaltungsangelegenheiten), also called "own area of responsibility" (eigener Wirkungskreis); and delegated matters (Auftragsangelegenheiten), also called delegated area of responsibility (übertragener Wirkungskreis). In matters of self-government, the principle of general powers (Allzuständigkeit) applies. ${ }^{64}$ According to this principle, which is somewhat comparable to home rule in the United States, the municipalities (and counties) in Germany have the authority to do anything they wish so long as it is within the framework of and does not conflict with a Land or federal law (Article 28, para. 2). In theory at least it stands in sharp contrast to the American ultra vires rule, according to which American municipalities may engage only in those activities authorized by their charters. In practice the Länder have not left their cities and towns all that much room to maneuver, so that the general powers rule, like Articles 30 and 70 of the Basic Law regarding the powers of the Länder and the federation, is somewhat misleading.

Matters of self-government include voluntary (freiwillige Aufgaben) and mandated tasks (Pflichtaufgaben). Voluntary tasks may in fact be required in the sense that they are needed and cannot be ignored. Or, on the other hand, voluntary tasks may not be performed owing to a lack of financial means or a lack of administrative capability. The focus of voluntary tasks is the provision of social, cultural, and economic public facilities and services. Examples of voluntary tasks are the construction and maintenance of swimming pools, athletic fields, lecture halls, libraries, museums, and, in larger cities, theaters; support of cultural associations and music schools; the provision of parks and green areas; the construction and maintenance of nursery schools, youth centers, retirement and nursing homes, hospitals, and so forth. Mandated tasks include, for example, waste collection; sewerage; public playgrounds; street construction and maintenance; fire protection; zoning; maintenance of elementary schools, and, for the city-counties, maintenance of secondary schools. ${ }^{65}$ 
Delegated matters are responsibilities that must be carried out by the municipalities because there are no general and direct state agencies at the municipal level for such purposes. Municipalities carry out fewer delegated tasks than the counties, but they are involved to some extent in this area of responsibility. There are no special authorities in municipalities. Delegated matters include passport administration; local registration of inhabitants and the provision of personal identity cards, which in turn is connected to registration for the military draft (or alternative civilian service); building supervision; care of the homeless and of refugees and asylum seekers. On the other hand various welfare tasks and the promotion of economic development and culture are mostly in the category of self-government matters. ${ }^{66}$

In their administration of matters of self-government, German municipalities are responsible for their actions, that is, they must operate within the law. For municipalities in the counties, this means they are subject to the legal supervision of the Landrat (or county manager) for the selfgovernment activities and to his or her functional supervision for the delegated activities. The Landrat, in turn, is supervised by the director of the government district who in turn answers to the various ministries. In those smaller territorial Länder without government districts, supervision is by the Minister of Interior. Supervision is carried out informally through routine consultation. The next stage usually takes the form of requests for information. In cases of noncompliance, the supervising authority can order compliance, arrange to implement measures at the cost of the municipality, or, finally, replace the local authorities with a state commissar, which was done on numerous occasions during the last difficult years of the Weimar Republic but only rarely in the Federal Republic. To prevent such extreme actions, there are various approval procedures, for example, for selling public property, borrowing money, etc. In cases of disagreement, municipalities can contest the decision of the supervisory authority before an administrative court. ${ }^{67}$

The lower level: the county-free cities In all of the Länder, there is citycounty separation (found as a rule in the United States only in Virginia) for the largest cities; therefore, as we have already seen, they are referred to as city-counties (Stadtkreise) or, more commonly, as county-free cities (kreisfreie Städte). The county-free cities are responsible for administering all local affairs and serve also as substitutes for lower state administrative authorities. The responsible organ is the governing mayor (or city manager until the 1990s) who, however, is not "on loan" to the state. Rather, 
he administers state laws as "delegated matters" of local government on his own responsibility. Again, there are no state administrative offices within the jurisdiction of the county-free cities, so that indirect state administration takes place here also. ${ }^{68}$ In both the rural counties and the county-free cities, then, the Land is relieved of establishing its own local agencies, and the administration of state tasks is carried out by those who are familiar with the local conditions and the people. At the same time local governments gain some understanding for the concerns of higher levels via contact with their agents. "[T] he leading and deeper idea behind the organization of the lower level is not that of a clean separation between two arenas, but communication, mutual exchange of information, and a balancing of state and local interests." 69

Administration of delegated state functions by the county-free cities falls under the functional supervision of the district government (see above); supervision of all matters of local self-government is legal only. In some Länder larger cities that are not county-free have been given similar rights and responsibilities. ${ }^{70}$

An especially important example of county and county-free city administration of delegated tasks is the public assistance (Sozialhilfe) that is provided by federal law to those who have exhausted their unemployment benefits or have no other source of income. This includes not only the handicapped and blind but also refugees and asylum seekers. This law has been delegated to the Länder, which in turn have given the actual administration of payments for living expenses to the rural counties and county-free cities as a matter of self-government. Since these local governments are responsible not only for administrative costs but also for providing the actual funds for payments, and since there has been relatively high unemployment in recent years among Germans and even higher rates among the many foreigners that have come to Germany, the financial stress of local governments has been exacerbated significantly by this responsibility.

The result has been considerable conflict between the different levels over current arrangements. Federal guidelines leave the local governments little room for maneuver, because benefits are supposed to be standard throughout the country. When the Public Assistance Act was revised in 1961, it was assumed that its importance would decline steadily owing to economic growth and affluence. The restrictions placed on local government autonomy in administering the program were therefore not taken very seriously. With the rise of long-term unemployment and the large numbers of refugees and asylum seekers, public assistance has 
become a major bone of contention between federal, Land, and local authorities. The dilemma facing the localities is that they do not have the revenues to assume responsibility for public assistance, and even if they did there are strong ideological and practical reasons for having a federal program with nation-wide standards. ${ }^{71}$

Youth and family assistance is also a delegated function that is a matter of self-government for the rural counties and county-free cities. This involves subsidies for nursery schools (Kindergarten); programs for music, sports, international understanding, youth consultation, etc.; and a variety of family social services and youth homes. Family promotion has been added in recent years in the Länder in the form of one-time payments for bearing children (Babygeld). This is in addition to monthly child support payments (Kindergeld) for all families. Educational promotion funds, for example, funds to pay for board and room costs of some higher school and university students (tuition is free) based on family income, are regulated nationally, but some Länder, for example, Lower Saxony, have added supplements for pupils attending higher secondary schools (Gymnasien) who cannot live at home because of the distance of the school from their place of domicile. ${ }^{72}$

There have been many complaints in Germany - as in the United States - about the growing influence of "the state" at the local level, especially in terms of mandated functions. A recent example is the federal law approved by the Bundesrat - that requires all municipalities to provide nursery schools for all children whose parents want them but without providing the funding for the schools. Thus some observers see the work of local governments as consisting more or less of administering statemandated and delegated tasks. This has also had a significant influence on the financial situation of the municipalities, and it raises constitutional questions about the guarantee of local self-government. ${ }^{73}$ It also raises questions about the extent to which the Bundesrat reflects the interests of local governments as opposed to broader party interests.

The lower level: special inter- and intramunicipal associations Some Länder, e.g., Lower Saxony, Rhineland-Palatinate, Baden-Württemberg, and Schleswig-Holstein, also have subcounty associations of villages and towns, somewhat like a local federation of small municipalities (called, respectively, Samtgemeinden, Verbandsgemeinden, Verwaltungsgemeinschaften, and $\ddot{A m t e r}$ ). In other cases some former villages or towns (Ortsschaften) that were consolidated into larger municipalities during the territorial reforms of the 1960s and 1970s were given certain limited responsibilities 
in compensation for their loss of autonomy. They are modeled to some extent on the intra-municipal city districts of certain large cities. Some special-purpose administrative associations have been formed in Bavaria, Saxony-Anhalt, and Thuringia; Bavaria, North-Rhine Westphalia, and Rhineland-Palatinate have higher- level multiple-county associations. ${ }^{74}$

In addition, many municipalities and counties have formed special districts (Zweckverbände), usually for a single purpose such as provision of drinking water, regional planning, constructing a swimming pool, regulating a river separating two political units, maintaining a common school bus, etc. ${ }^{75}$ While these are common features of local government in Germany, they are not as ubiquitous as in the United States.

The lower level: special supra-municipal associations In some Länder associations of municipalities have been created at a regional level in order to carry out certain functions that cannot be administered effectively at the municipal or county levels. The best examples are the two regional associations (Landschaftsverbände Rheinland and WestfalenLippe) in North-Rhine Westphalia, which are in the process of being reformed and replaced; the seven districts in Bavaria; and the Bezirksverband Pfalz in the Rheinland-Palatinate. There are also Land welfare associations in Baden-Württemberg, Hesse, and Saxony as well as the regional planning associations in Baden-Württemberg. An innovative regional association was formed by Stuttgart and five surrounding counties in 1994 , and it has a wide range of planning and coordination functions. ${ }^{76}$

\section{Administration in the city-states}

Unlike any other existing federation, Germany has three city-states: Bremen, Hamburg, and Berlin. The first two have their origins in the Holy Roman Empire as trading cities that were important participants in the Hanseatic League, while Berlin's status is the result of the city's division during the Cold War, its unification in 1990, and the failure of a referendum in May 1996 that, if successful, would have led to a consolidation of Berlin and Brandenburg.

Bremen is not a simple city-state, but rather a two-city state. Unlike Hamburg and Berlin, which are unitary cities, Bremen consists of the cities of Bremen and Bremerhaven, separated by $65 \mathrm{~km}$ with territory from Lower Saxony in between. The governmental organs (Senat) and parliament (Bürgerschaft) of the Land Bremen also serve the city of Bremen, but Bremerhaven has its own city government and council in addition. ${ }^{77}$ 
In Bremen and Hamburg the high-, middle-, and lower-level Land functions are combined to a considerable extent. The advantage, of course, is less distance between the citizen and government officials and administrators; the disadvantage is the resulting complexity of city administrative organization. In all three city-states neighborhood or district offices have been created, but they have fewer powers in Bremen than in Hamburg or Berlin.

In Hamburg there is no separation between the "state" and "municipal" administration. The city, like Bremen, has a lord mayor as head of government (Senat) and a parliament (Bürgerschaft). The city is divided into districts which are not autonomous but do provide "deconcentrated administration." The districts have elected assemblies and an administration that implements measures that do not require a larger area. ${ }^{78}$

Unlike the other two city-states, Berlin has two administrative levels, but it is different from the territorial Länder that have two levels (e.g., Schleswig-Holstein and Saarland). It is not a traditional city-state like Bremen and Hamburg, which were city-states before the war and the division of Germany after 1945. Berlin became a divided city-state under Allied occupation during the Cold War; it was reunited in the summer of 1990, and in June 1991 the Bundestag decided by a close vote to make it the national capital again. In 1994 the city completed a constitutional and administrative reform that was to prepare it for its future responsibilities at least until consolidation with Brandenburg; however, the referendum that was to bring this about failed in May 1996, so that Berlin's new legal framework may last longer than many expected.

As in the other city-states, there is no difference between state and local government administration. The tasks of the city as municipality, county and Land are met by the parliament (Abgeordnetenhaus), government (Senat), and administration, including administration by the twenty-three districts into which Berlin was divided (In 1999 the twenty-three districts were reduced to twelve). There is, then, a high or main administration and a district administration. These two levels have existed since 1920, when Berlin annexed eight cities, fifty-nine towns and villages, and twenty-seven estates. The division of the city into the then twenty districts was designed in part to compensate the incorporated areas for their lost status. ${ }^{79}$

There are three categories of tasks or responsibilities in Berlin: the tasks of the main administration; the tasks delegated to the districts under the supervision of the city; and district tasks. The 1994 Berlin constitution enumerates the powers of the main administration and those that can be delegated. What is not enumerated belongs to the districts. Federal laws 
that are delegated to the Länder are divided in Berlin between the main administration and the districts which, like local governments in the territorial Länder, implement these laws as matters of their own responsibility. The districts are responsible for such matters as schools, adult education, hospitals, libraries, swimming facilities, youth homes, athletic fields, parks, and music schools. Delegated matters under supervision include building plans, street maintenance and lighting, elections, and property issues. The districts can make their own zoning plans, and they enjoy some fiscal autonomy. The main administration is responsible for general law and order, constitutional protection, relations with the federal government, asylum seekers, citizenship issues, money and credit, city-wide planning, public housing, etc. ${ }^{80}$

Unlike the typical territorial Land described on p. 87, the "chancellor principle" does not apply to the city-states. According to this principle, the prime minister is elected by the Land parliament and then appoints his cabinet members. In each of the three cities, however, the lord mayor is elected by the city parliament which also elects the members of the cabinet. The city parliament can also remove cabinet ministers in a vote of no-confidence. In practice, of course, the parliament elects the cabinet nominees already selected in negotiations within the majority party or majority coalition. In any case the lord mayor does not have the power to set the guidelines of policy as do his counterparts in the territorial Länder, that is, the principles of collegiality and ministerial responsibility are stronger in the city-states. ${ }^{81}$

\section{Special agencies}

As noted above, a distinction is made in Germany as in the United States between general- purpose and special-purpose administration. We have seen that there are a good many special agencies in Germany. At the federal and Land levels special offices are common. These serve at the federal level in place of missing substructures, but they are subunits of the various ministries at the Land level..$^{82}$ They are seen usually as means of relieving the ministry of an administrative burden in favor of greater decentralization, but sometimes they are also seen as centralizing agents. They are usually at the higher level of administration, that is, below the supreme and above the middle levels; however, some are also at the middle level, where they may be to some extent in competition with the district government. They tend to be technically demanding, e.g., statistical offices, or responsible for certification functions, e.g., geological 
offices. The Gewerbeaufsichtsämter can be found between the middle and lower levels. ${ }^{83}$ These are special authorities established for the purposes of supervising business operations regarding workplace health and safety standards, noise levels, temperature conditions, radiation, abuse of workers or animals, and protection of nature, and so forth.

At the lower level there is considerable administrative fragmentation, in spite of unity of command in the rural counties and county-free cities. This is more evident in the south (Baden-Württemberg, RhinelandPalatinate, Bavaria) than in the north (North-Rhine Westphalia, Hesse). Examples of special authorities that are not easily integrated into the rural counties and county-free cities because of the territory they cover or their specialization are weights and measures (Eichämter); mountain and forest offices; and cultural and road construction offices. Regional development and environmental protection can also be difficult to integrate within a local unit of general administration. ${ }^{84}$

\section{Indirect administration by nongovernmental public bodies and private persons}

Direct administration by "state" (Land and federal agencies at various levels) and indirect administration by self-governing local governments do not exhaust the forms and instruments of administration in Germany. Indirect administration by self-governing nongovernmental public corporations, institutions, and foundations is also important. Public territorial corporations have members - those living in the territory - and autonomy, for example, municipalities and counties. Universities, on the other hand, are personnel corporations. Public institutions (Anstalten) have the function of carrying out a particular purpose. They have no members, only users; examples would be the Sparkassen, which have a monopoly as savings and loan associations, or public radio and television networks ${ }^{85}$ sponsored by the Länder. Public foundations are institutions that have a continuing purpose set by a founder with funding provided by an endowment from public and/or private sources. All of these legal forms of service providers share a degree of autonomy or the right of self-government of their affairs, subject only to the legal supervision of ministries.

\section{Social insurance agencies ${ }^{86}$}

Next to the local governments, social insurance is the most important area in which indirect state administration is carried out. The Federal Employment Office in Nuremberg is responsible for providing unemployment 
compensation as well as employment counseling and other services such as child support payments for all children in Germany. It is a semiautonomous federal institution (Anstalt) with branches at Land and local government levels. ${ }^{87}$ Social insurance agencies that provide health and retirement benefits with responsibilities above the Land level are federal bodies (that is, special public corporations carrying out federal law), of which there are several examples.

Social insurance for health, accident, retirement, and, most recently, nursing care programs is provided by federal law, but administration is not by government agencies. All employees who earn less than a certain amount per month -90 percent of the employed - are required to join a health insurance provider. In the past there were insurance providers restricted to special occupations or groups of employees as well as providers for the general population. Since the beginning of 1996, employees may select their provider; however, each provider must offer a uniform system of services and quality standards, and no one may be refused admission. Therefore, the price competition among the different providers will be based primarily on the efficiency of their operations, although there is some concern that the effect of this reform will work to the disadvantage of the rapidly growing older population. ${ }^{88}$

The public corporations that provide insurance are semi-autonomous institutions that implement the social insurance law as matters of their own responsibility. In most cases an assembly and executive committee are elected with equal representation for both employers and employees; social insurance funds for miners, where the insured make up two-thirds of the self-governing organs, are an exception. Eligible voters for the assembly elections are the insured employees.

In the early 1990s there were about 1,235 sickness funds organized in a variety of forms. The largest number of insured are with 274 regional funds (Ortskrankenkassen, AOK). There were also 747 funds organized by companies (Betriebskrankenkassen), 176 funds offered by vocational groups (Innungskrankenkassen), twenty-one funds for farmers, one for seamen, one for miners, and fifteen voluntary "substitute" funds. By the end of 1999, these numbers had been reduced sharply to seventeen regional funds, 354 company funds, thirty-nine vocational funds, and nineteen substitute funds. ${ }^{89}$ Minimum numbers of insured are required; e.g., 100,000 for the company funds, 1,000 for a vocational fund..$^{90}$ All public sickness funds are supervised by the district governments and Land, while private funds are supervised by the federal insurance office. 
Retirement programs are divided among three large branches. The first is for manual workers, which is organized into Land insurance institutions and institutions for federal railway workers and seamen. The second is for white-collar or salaried workers which is run by the Federal Insurance Agency for Employees in Berlin. And the third is the Retirement Insurance Agency for Mine Workers. Farmers were added in 1957, their family members in 1985. Independent journalists and artists were added in 1981, and as of 1986 mothers receive credit for retirement insurance based on the number of years they were engaged in child-rearing activities. ${ }^{91}$

Other significant institutions in the area of social insurance are the nongovernmental "free providers and associations." The most important of these are churches and religious societies as well as groups of private welfare providers. These are engaged in the "workers' welfare assistance," or the German Red Cross, German Caritas, the Jewish Central Welfare Center, and so forth, located at different levels of government. German Christian - especially Catholic - social doctrine focuses on the principle of subsidiarity, according to which public policies should be carried out at the lowest level possible. This principle has been adopted to a considerable extent by federal law makers, who have delegated to or authorized private, nongovernmental agencies to carry out numerous social welfare functions with considerable public financial support. Thus before unification private welfare providers (freie Wohlfahrtsverbände) sponsored 40 percent of the hospitals for acute treatment, about 60 percent of the retirement homes, about 70 percent of facilities for youth, and 60 percent of the facilities for handicapped persons. Continuing education, especially in the form of adult education, is also a major activity. In the 1980s there were about 900 adult education centers (Volkshochschulen) which were being turned over increasingly to local governments which provided about two-thirds of their funding. ${ }^{92}$

\section{Chambers}

There are numerous self-governing nongovernmental public corporations, or chambers, in the Länder that are designed in part to relieve the ministries, to which they are responsible, of some administrative tasks. In the process, they are performing indirect Land administrative functions. They all have certain common characteristics: required membership; an assembly, directly elected by the members as defined by law; a board elected by the assembly and a professional manager; and a president elected to represent the concerns of the chamber in the broader community. ${ }^{93}$

The chambers can be broken down into various categories. In the economic area, for example, one finds chambers of industry and commerce, 
chambers of tradesmen/craftsmen, and agricultural chambers. In the area of free professions, there are chambers of attorneys, somewhat comparable to state bar associations in the United States; and chambers of physicians, dentists, pharmacists, architects, and so forth. The chambers see themselves more as agencies assisting the state in numerous administrative tasks than as typical interest groups. ${ }^{94}$

Especially well-known chambers are found in the economic area. Every Land, for example, has at least one agricultural chamber, membership in which is required of all farmers. This chamber is financed in part by a modest assessment on the members based on the value of their property and collected by the tax authorities. Some income is received from fees, and at least half to two-thirds of the income comes from the Land. The chamber is governed by a policy making assembly, elected by the members, a ceremonial president, and a professional director and his staff. Traditional tasks of promoting agricultural interests are joined by other tasks delegated by the Land. The chamber administration has sections for agricultural technology, animal husbandry, training and continuing education, plant and seed protection, forestry, and so forth. It also operates numerous vocational schools and experimental farms..$^{95}$

Two other examples of well-known economic chambers that work with the Ministry of Economics are the Chamber of Tradesmen/Craftsmen and the Industry and Commerce Chamber. Membership in both is required and is represented by an elected assembly and officers. The Chamber of Tradesmen/Craftsmen is responsible for training programs for apprentices and for the examinations that lead to certification as journeymen (Gesellen) and master craftsmen. The territory covered by such a chamber usually conforms to that of a government district. The Industry and Commerce Chamber consists of natural persons, commercial enterprises, and legal persons that operate a business in the territory of the chamber. The chamber is financed by set contributions and by assessments based on the volume of sales. Small business members pay no assessment and only one-half of the set contribution. The task of the chamber is to represent the interests of the members as a whole. It provides reports on the status of businesses, sets ethical standards, establishes mediating boards for disagreements among members, takes measures against unfair competition, regulates conditions of sales, and handles consumer complaints. It engages in numerous other activities as well, such as registering business enterprises, certifying various activities, inspecting grocery stores, and providing consulting services. Like the agricultural chambers and the chambers of tradesmen/craftsmen, it is also responsible for training programs and vocational education. ${ }^{96}$ 
Chambers of the free professions are numerous but not all-encompassing, given the differences that exist among the wide variety of practicing groups. Free professions form chambers because of the special relationship they have with clients or patients, a nonmaterial relationship of trust involving a special responsibility to society. Free professions, in spite of their "freedom" and self-determination, are bound by certain obligations and rules, e.g., formal admission procedures, fee structures, and prohibitions on advertising. All free professions are organized in chambers, membership in which, again, is required. Nevertheless, not all groups are included. Thus in the health professions, there are chambers for physicians and pharmacists, but not for homoeopaths, midwives, dental technicians, and physical therapists. There are chambers for attorneys, notaries, tax advisers, and accountants, but not for business consultants, salesmen, or driver training instructors. Nor are there any chambers for scientific, artistic, educational or journalistic professions. ${ }^{97}$

\section{Universities and specialized schools of higher education}

(Fachhochschulen)

Institutions of higher education enjoy academic freedom as a constitutional right and have the right of self-government "within the framework of the laws." In general these are Land laws, but these reflect the provisions of the Federal University Framework Law of 1976 in the creation of which the Länder participated. Thus, while laws vary by Land, they share many common features. In Lower Saxony, for example, the Senate, the organ responsible for routine academic affairs, including hiring of faculty, consists of the deans of the schools as a consulting group and four groups who have the decision making powers: professors; students; academic assistants, research aides, etc.; and employees in the technical and administrative services. Actual representation in this "group university" takes place in the proportion of seven professors, two students, two academic aides, and two "others." The concept of the "group university" originated during the late 1960s, when students engaged in a general revolt against older academic structures. At first there were three "groups": faculty, broadly defined; students; and "others," including administrative and technical personnel. Each group had an equal voice. The Federal Constitutional Court ruled in 1973 that the professors must have a majority of the votes in matters involving teaching and research, and the system described briefly above emerged as a result. ${ }^{98}$

The highest official of the university is the president, elected by the Konzil, a central university organ consisting of more than 100 faculty, for 
a term of six years. The Konzil also elects the chief administrative officer, the chancellor. Other institutions of higher education, such as the art schools and the specialized colleges (Fachhochschulen), are led by a rector, who is elected from the faculty for two years.

The next level of university administration consists of the general subject areas (Fachbereiche), roughly similar to schools in the United States, headed by an elected dean who serves a two-year term. Students are automatically members of the "student body" which is represented by a student parliament and a general student committee ( $A S t A)$ that provides a number of student services. ${ }^{99}$

\section{Public radio and television ${ }^{100}$}

Since the electronic media fall under the concept of "culture," programming and broadcasting are the responsibility of the Länder, however, the federation is responsible for technical matters. Until the mid-to-late 1980s, when private satellite and cable television were introduced after considerable controversy over their potential effects, ${ }^{101}$ all radio and television in Germany was public, which meant sponsored by the Länder. Each of the individual Länder has the right to create its own network, and many have done so. Thus Bavaria, Berlin, Brandenburg, Bremen, Hesse, North-Rhine Westphalia, and the Saarland have their own radio and television networks operated by autonomous boards. The other Länder have joined in various combinations to form a joint network. The North German Network consists of Lower Saxony, Hamburg, Schleswig-Holstein, and MecklenburgVorpommern, and the Central German Network is composed of Saxony, Saxony-Anhalt, and Thuringia. In the south of Germany a part of one Land (Württemberg) sponsors the South German Network and another part (Baden) has joined with the Rhineland-Palatinate to form the Southwest German Network. ${ }^{102}$ In April 1997 these two networks agreed to join into one Southwest German Network. ${ }^{103}$ There are ten public broadcasting networks (legally, "institutions") sponsored by the Länder. Each network offers its own radio programming over two-eight channels, and each has one regional television channel which it may share in part with other networks.

In 1950 the public broadcasting institutions in the Länder formed the Working Group of Broadcasting Institutions (ARD), an "umbrella institution" that runs a nationwide television network known as "the first program" and regional networks referred to collectively as "the third program." A second network for television only is called in German "the second program" (ZDF); it was created in 1961 on the basis of contracts 
with all of the Länder after an attempt by the Adenauer Government to form a federal network was ruled unconstitutional by the Federal Constitutional Court. ${ }^{104}$

All of these networks are financed largely - more than 80 percent - by nonvoluntary fees paid initially via the post office and since 1976 to the License Fee Office (GEZ) operated by the ARD and ZDF. The fees are set by the Land parliaments of all the Länder and amounted in the late 1990s to DM 28.25 per month (after 2001, DM 33.33) per household for television and radio. The fees are divided by a ratio of 64:36 between the ARD and ZDF. The ARD then transfers funds to the various Land networks based on their size. Commercials also provide some income, but they are subject to restrictions; for example, they are limited to 20 minutes a day and are not allowed after 8.00 p.m. or on Sundays and holidays and not at all on the "third program." 105 The financing of the public radio and television networks is a major theme at the prime ministers' conferences. ${ }^{106}$

The networks are operated by a director and supervised by an administrative council of usually eight-ten members and by a larger board consisting of up to fifty representatives from the parties in parliament, arts and sciences, religious groups, management and labor, and social organizations. This internal pluralism is supposed to ensure nonpartisan, comprehensive programming. Just how nonpartisan the politically oriented programs really are is subject to considerable debate, because some are obviously slanted to the left or right. While political parties normally have no more than one-third of the membership, their influence is reflected by other group representatives as well. ${ }^{107}$ Nevertheless, "there is obviously a systematic confrontation and counterbalance of political orientations" in the public systems, that is, "no single political party has ever enjoyed undue influence over the entire public-service broadcasting system." 108 Therefore, there seems to be little doubt that the networks are basically independent. ${ }^{109}$

ARD and ZDF together offer a cable network, SAT 3, for an additional fee, and they have begun new channels for children and news-oriented programming. They also joined with a French network to offer ARTE, which is more culturally oriented. Networks across Europe have joined in a European Broadcasting Union (EBU) to offer "Euronews" as an alternative to $\mathrm{CNN}$.

There is another public broadcasting network at the national level which is operated by the national government under its authority for foreign affairs. Thus radio and television programs are broadcast to foreign listeners, and while German Radio (Deutschlandradio) can be heard also 
in Germany, the television broadcasts (Deutsche Welle) are available only outside the country.

As noted above, private television and radio broadcasting was introduced only in 1984. This created the "dual system" of public and private stations in Germany today. ${ }^{110}$ Rather than "peaceful coexistence" between the two systems, controversy has arisen over several issues. In the first place, the public networks, $\mathrm{ARD}$ and $\mathrm{ZDF}$, are required to offer complete, high-quality programming. Private channels offering specialized programming or little more than entertainment have attracted large numbers of viewers, and they have also attracted most of the money for commercials. Competition has also led to a dramatic increase in the costs of broadcasting, for example, for major sporting events and movies. These rising costs have placed the public networks at a serious disadvantage

Thus, Radio-Television-Luxemburg (RTL), based in Cologne, appeals especially to younger people and is now the most-watched German television network, with more than 16 percent of market share. ${ }^{111}$ Together with SAT 1, which features movies and sports and operates 24 hours a day, these two private channels have as many viewers as the public networks. Indeed, private commercial television now has about 60 percent of the total viewership. ${ }^{112}$

\section{Public savings and loan associations (Sparkassen)}

Sparkassen were established in Germany to encourage savings and to provide credit to the local community with particular focus on the middle classes and weaker social groups. The responsible sponsors are larger municipalities and rural counties. They are governed by a council, members of which come from the local elected city or county council, and by a two-member management board elected by the council. They are supervised by the district governments. Together the various Sparkassen form a Land association under the supervision of the Land Minister of Finance. ${ }^{113}$

\section{Foundations}

Foundations exist under public, civil, and private law. An example of a private law foundation would be the VW Foundation which promotes research in science and technology. A well-known public foundation under federal law is the Foundation for Prussian Cultural Treasures, which maintains libraries, archives, museums, etc., that belonged to the state of Prussia. An example of a Land foundation is the Lower Saxony Foundation that provides financial support for cultural activities that the Land does not or cannot finance, in part due to lack of funds. Its endowment comes 
from an initial bloc of money received from the Land, from gifts from certain large businesses and banks, and from private persons. Foundations are most common with respect to the maintenance of certain churches, monasteries or convents, and to the provision of funds for cultural activities. They were much more common in the past than today. ${ }^{114}$

\section{Water and ground associations}

In Lower Saxony, as an example of one Land, there are about 2,000 associations that deal with water and ground issues, including drainage, sewerage, and water supply. There are numerous dike associations of which all land owners in certain areas are required to be members. Costs for the dikes and their maintenance are covered by the Land; the federal government by way of the federal-Land "joint task" responsibility for improving agricultural structures and coastal protection (Article 91a of the Basic Law); and by the property owners. Forestry associations and hunting and fishing associations are supported by the rural counties. ${ }^{115}$

\section{"Borrowed" instruments ("Beliehene")}

Certain institutions, groups, or individuals can also be engaged in administration due to some kind of expertise. Chimney sweeps report on fire and building conditions, emissions, and energy use in making their required periodic checks of heating systems in homes and businesses, and property owners are required to correct defects that have been detected. The private technical inspection service ( $T \ddot{U} V$ ) performs the required biennial inspections of safety conditions of all cars and trucks. And, owing to the nature of their positions, ship captains and airplane pilots can exercise certain state responsibilities for maintaining safety and order. ${ }^{116}$ Other examples include game wardens, bankruptcy administrators, some notary publics (specialized attorneys who offer certain key legal services), certified private schools, private welfare providers, and so forth. ${ }^{117}$

\section{Planning in the Länder}

\section{General}

Given the recent experience of the Nazi regime and the then current example of the communist system in East Germany, there was a certain amount of suspicion in the first years of the Federal Republic against planning beyond zoning and budgetary plans. But some planning did 
exist, for example, in agriculture (Grüner Plan), youth affairs (Bundesjugendplan), and with respect to roads, sports, and some other matters. The Länder also engaged in some planning, especially for refugees and education. The main characteristics of this first planning phase were isolated sectoral planning; individual infrastructure planning with unsophisticated methodologies and little consideration of financial resources; and little federal-Land cooperation. ${ }^{118}$

In the period 1966-69, there was a dramatic change in the attitudes and practices in Germany regarding planning. This was reflected, for example, in the Federal Law of 1967 on the promotion of stability and growth of the economy. This led to framework planning for the entire economy, or "global direction," on the basis of medium-term goal projections and multi-year financial planning at the federal, Land, and local levels. It also produced coordinating agencies, such as the financial planning council and the economic cycle council and, finally, the corporatist "concerted action" at the federal level involving consultations among state officials, large firms, and unions. ${ }^{119}$

The Finance Reform of 1969, which brought about several major changes in the Basic Law, included two articles dealing with "joint tasks." Article 91a deals with federal-Land cooperation in university construction, improvements in regional economic structures, and improvements in agricultural structures and coastal protection, each of which involves a joint planning committee, medium-term framework planning for investments, and/or subsidies and joint financing. In 1970 a federal-Land commission for educational planning was created under Article 91b.

A federal territory planning program was started, and planning staffs and planning groups were established in all of the ministries and in the Chancellory. In the Länder work began on "Land development plans" and numerous functional and regional plans. In larger cities there were city development plans. Characteristic of this phase was the intensification and perfection of already existing planning efforts, e.g., federal highway planning and Land development planning; the introduction of a qualitative new role for financial planning and direction of the economy, and new planning units in the general administration; the securing by legislation of middle-range planning in the areas of finance and joint tasks; and the belief that joint federal-Land planning was necessary under "cooperative federalism." 120

After 1975 there was a period of critical distance from planning, due in part to the oil crises of 1973 and 1980 and rising unemployment. This called more for short-term crisis management than for long-term planning, and 
it undermined plans already made. Revenues were now below projections and indebtedness rose. New problems, including demographic changes, rising health costs, and environmental concerns led to more skepticism toward planning, and planning staffs were reduced in size and their tasks limited. Planning continued as a routine activity, but ambitious systems of development planning were dropped. Crisis management with narrower concerns and a shorter range of planning became especially prominent at the local level. This has led to a renaissance of functional planning with a reduction in expectations of vertical and sectoral coordination. But in comparison to 1965 there is functional planning in more policy areas than before; it is methodologically more sophisticated; and there is more areal, financial and procedural coordination. ${ }^{121}$

\section{Types of planning}

At the federal level, the Basic Law requires or authorizes five kinds of planning: budget planning; finance planning, which is above all resource planning but also functional planning; defense planning; framework planning under Article 91a; and educational planning under Article 91b. The latter two will be discussed below, since they involve the federation and the Länder.

The Länder also engage in budget planning and five-year finance planning by the Minister of Finance. More specific to the Länder is functional or sectoral planning for responsibilities such as roads and education (projections of pupils, teachers, building needs) and regional land-use planning. Municipal building and zoning plans must conform to these plans, but local officials have a voice in the process before it is completed. ${ }^{122}$

Regional land-use planning is one of the most important examples of Land planning, and it is probably the best example of attempts to coordinate and integrate various sectors of planning sometimes involving federal, Land, regional, and municipal efforts. ${ }^{123} \mathrm{EU}$ planning regulations are also of growing importance, e.g., in highway and railway planning, in nature preservation and the environment in general. ${ }^{124}$ An American study of land-use planning in Germany has noted the crucial importance of the constitutional principle of "uniformity [Einheitlichkeit] of living conditions" found in Article 72 of the Basic Law for an understanding of such planning. ${ }^{125}$ Article 72 is the basis for the federal concurrent legislative authority to pass the federal framework law on land use (Raumordnungsgesetz $(R O G)$ ) of $1997 .{ }^{126}$ But land-use planning is also based on the German concept of the "social state."127 
The ROG provides for vertical coordination of land-use planning among the federal ministry for regional planning and construction, Land ministries, and local governments, and for horizontal coordination between the latter two levels. Another means of cooperation and coordination is through various committees and councils, including the conference of Land ministers of regional planning. Implementation of the goals of the ROG is the responsibility of the Land planning process. Land law provides for the organization of planning at the Land and local levels. Individual land-use plans established by the Länder determine long-term goals and include data on population, employment, economic development, education, transportation, etc. The ROG places particular focus on the environment, including nature preservation. Land officials also review local county and city plans and encourage coordination and cooperation. ${ }^{128}$

The most important elements of regional planning today focus on the "central places," i.e., cities and towns that have been selected by the Länder as service providers and communication centers for their surrounding areas. ${ }^{129}$ These centers are key instruments in achieving the goal of "equivalent" living conditions, because they provide the surrounding areas with the necessary economic, financial, medical, educational, cultural, and other services and opportunities. ${ }^{130} \mathrm{~A}$ somewhat related activity is regional municipal planning, such as that established by Baden-Württemberg in 1994 for the city of Stuttgart and five surrounding counties. Its activities include regional territorial planning, traffic and commuter planning, regional economic and tourism planning, and waste disposal planning. It can require municipalities to formulate local zoning plans in conformity with regional plans. The agency has been given some popular legitimacy via an elected regional assembly consisting of eighty delegates. ${ }^{131}$

The ROG provides for the development of the territory of the Federal Republic so that, among other goals, "uniform" or "equivalent" living conditions will be achieved. As noted in Chapter 2 on the constitutional framework of German federalism, "uniform"- it was changed to "equivalent" in 1994 - did not mean equality in the sense of some kind of leveling process. ${ }^{132}$ Rather, these terms meant then and still mean today providing the necessary infrastructure, environmental conditions, employment opportunities, educational and cultural services, etc., that are required of a "social state."133 Nevertheless, there was misunderstanding of "uniformity," in that some politicians and others interpreted the term too literally. ${ }^{134}$ After unification and the recognition of dramatic differences in the living conditions of the eastern and western parts of Germany, it became evident that "uniformity" was misleading at best and that the conditions 
in the eastern part of united Germany required new thinking. ${ }^{135}$ For all of these reasons, the term "uniform" was changed in the constitutional reform process of 1994 to "equivalent," but it is not clear that this change will have much effect. In the meantime there is less emphasis on either term today and increasing use of the concept of "comparable living conditions" for the eastern Länder. This discussion has led to considerable controversy, however, because it raises the question of more federal assistance to achieve "equivalent" living conditions at the cost of Land autonomy.

\section{Joint task planning}

A continuing example of federal-Land planning, which is an otherwise generally discouraged example of "mixed administration," can be found in the "joint tasks" provisions of Article 91a and 91b that were described briefly above and in Chapter 2 on the constitutional framework of German federalism. ${ }^{136}$ Article 91a and 91b were added to the Basic Law in 1969 as part of the larger Finance Reform of that year, because of the consensus in the German parties that a strict separation between the federation and the Länder in a number of areas was no longer appropriate and constitutional reality required cooperation. Article 91a permits the federation to participate in the construction of university facilities, including medical clinics; in the promotion of regional development; and in making improvements in agriculture and coastal protection. It provides for federal financing of 50 percent of university construction and regional development and 50 percent or more of agriculture improvements and coastal protection. In practice the federation's share has been 60 and 70 percent, respectively, for these latter two areas. ${ }^{137}$

This cooperation requires joint planning between the federal and Land governments, the procedures for which are provided in three federal implementation laws passed by the Bundestag and Bundesrat. Each of the three areas designated as a joint task has a planning committee. The members are the federal and Land cabinet ministers responsible for the subject matter of each committee, together with the federal finance minister. The federation has sixteen votes, which must be cast as a bloc, and each Land has one vote. A majority consists of the votes of the federation and a majority of the Länder. The plans developed and approved are, however, framework plans; detailed planning is left to the Länder, as are all other executive functions connected with the joint task in question. ${ }^{138}$

Once the joint framework plans have been approved, the governments in effect are bound to include the measures in their next budget. This, of 
course, presupposes parliamentary approval. Approval can be denied, but there is a common trust that each government will be able to abide by the bargain. On the other hand, a Land can refuse to implement the actions in its territory, or it can go beyond the agreed plan as long as its actions are not in conflict with the provisions of the plan. Budgetary autonomy is upheld in that the amounts approved are decided by the parliaments, but they cannot in good faith cut off funds to the extent that action is undermined. Once the budget is approved, the Land or federation is committed. Problems can arise when municipalities have plans that are not in conformity with the general plan, in which case the Land may be required to interfere based on its right of legal supervision of local actions. ${ }^{139}$

While Article 91a mandates federal-Land cooperation, Article 91b authorizes it in the areas of educational planning and in the promotion of research institutions and plans that are of general or national importance. As in the case of Article 91a, Article 91b provides a constitutional foundation for cooperative practices (zusammenwirken) that were already taking place. For example, the German Education Council (Bildungsrat) was formed in 1965, while the Science Council (Wissenschaftsrat) was created as early as $1957 .{ }^{140}$

Article $91 \mathrm{~b}$ was added to the Basic Law at a time when there was a great deal of confidence in and enthusiasm for planning in general. A Federal-Land Commission for educational planning and promotion of research was formed in 1970, and it set about to create a "joint long-term framework plan for a coordinated development of the entire educational system" together with a joint educational budget. ${ }^{141}$ For a variety of reasons, including conflicts between the national government and Land governments, partisan conflicts, and financial considerations, the planning process proved to be more complicated than had been anticipated in 1970. While there was agreement on a Framework Plan in 1973, it did not result in exercising any "significant influence in controlling and coordinating the political activities of the individual Länder." ${ }^{142}$ In the meantime economic conditions had changed in Germany, partisan conflict in various areas increased, and general educational planning under Article 91b ended altogether in 1982, largely for partisan and financial reasons. Once the more conservative Christian Democrats and Liberals replaced the more planning-oriented Social Democrats in the national government in October 1982, the downsized Commission began serving as a forum for discussion between the national government and the Länder rather than as an agency for planning. ${ }^{143}$ 
In the case of Article 91b, federal-Land educational planning may have failed, ${ }^{144}$ but cooperation continues in other areas. Cooperation in scientific research, which would normally be a Land responsibility, has an important national purpose and continues unabated, as is seen, for example, in joint support efforts for the Max-Planck Institutes and the German Research Association (Deutsche Forschungsgemeinschaft). ${ }^{145}$ Indeed, a socalled "Blue List" contains the names of about fifty research institutions and museums that fall under Article 91b. ${ }^{146}$

As was noted in Chapter 2 on the constitutional framework of German federalism and will be noted in Chapter 5 on finances, there has been a good deal of criticism of Article 91a and 91b and the joint tasks they authorize. Probably the most fundamental and certainly the best known is the criticism by Fritz Scharpf, who notes that there is a tendency in joint programs which are based on unanimous or near-unanimous decision making to involve a "joint-decision trap" which leads to a number of undesirable consequences, including increased expenditures. ${ }^{147}$ Other criticisms include the argument that the Land parliaments are too little involved; that the federation has too much say in the financing of projects; and that the "mixed administration" involved violates the principle of division of powers between responsibility for legislation by the federation and for administration by the Länder. In reaction to these and other criticisms, the argument can be made that planning is in principle an executive function in which the parliaments are not well equipped to participate but can, instead, control to some extent; on the other hand, the Länder now give their framework plans to their parliaments before presentation in the joint commissions, and at the federal level the Ministry of Agriculture shows its plans to the Agriculture Committee of the Bundestag during the planning process so that questions regarding the framework plan can be raised in time for some parliamentary control. One response to the criticism that mixed administration violates the Basic Law is that the constitution does not require a strict separation of functions between the federation and the Länder. ${ }^{148}$

\section{Public employees}

\section{Classification}

In 1997 there were about 4.6 million public employees in Germany in direct administration and excluding former employees of public 
enterprises, e.g., railway workers (Tables 3.1, 3.2). This represents a little more than 12 percent of the total work force. Public employees are divided into two general classifications. One is the long-established division among civil servants (Beamte); salaried employees (Angestellten); and blue-collar workers (Arbeiter). The other classification is the division of the above categories into the simple (einfachen), the middle (mittleren), the elevated (gehobenen), and the higher (höhere) service levels. For the higher service level a university background is required, usually a law degree but increasingly a degree in economics; ${ }^{149}$ for the elevated service, the selective secondary school degree (Abitur) and, increasingly, a specialized college background (Fachhochschule) is the normal precondition. The middle level usually requires the mittlere Reife, roughly equivalent to an average American high school degree. There are no special educational

Table 3.1 Basic categories of public employees in direct administration in Germany, 1999

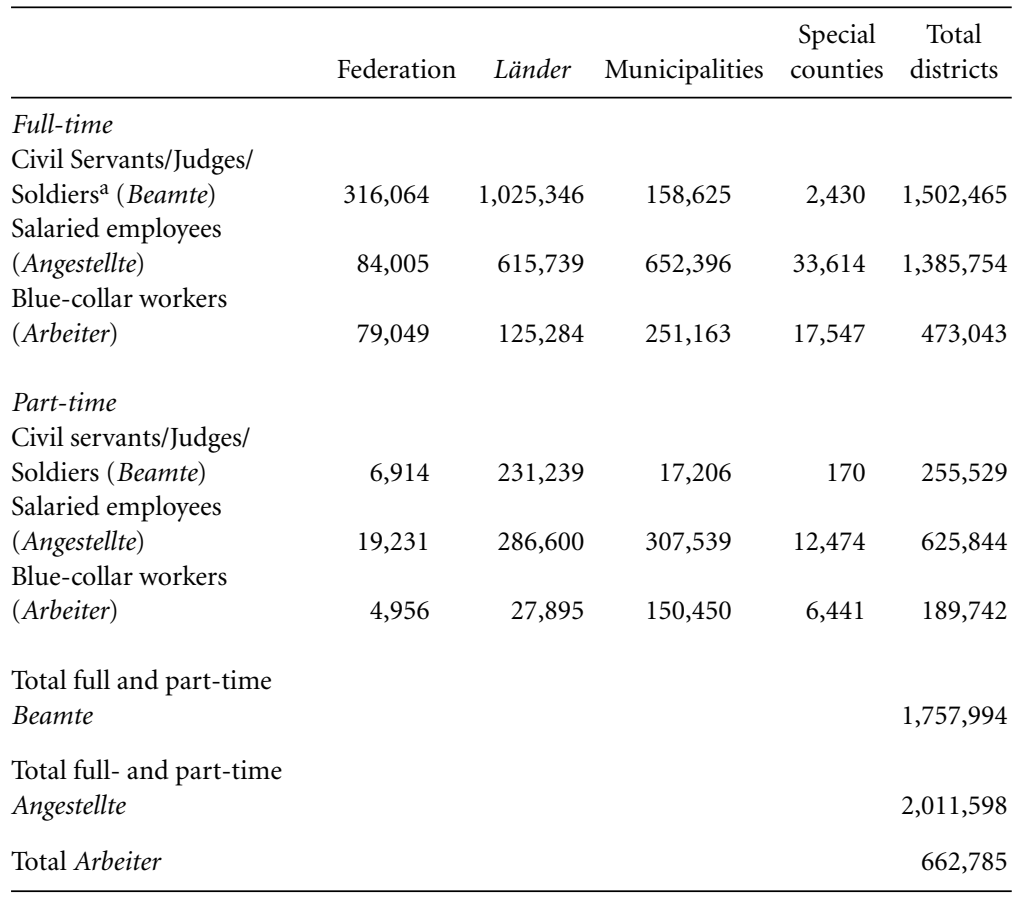

Note: ${ }^{\text {a }}$ Career and longer-serving soldiers only (c. 60 per cent of total Federal Beamte).

Source: Adapted from Federal Statistical Office, Statistical Yearbook 2000 (Stuttgart: Metzler-Poeschel, 2000), p. 516. 
Table 3.2 Classification of basic categories of public employees in Germany, 1998

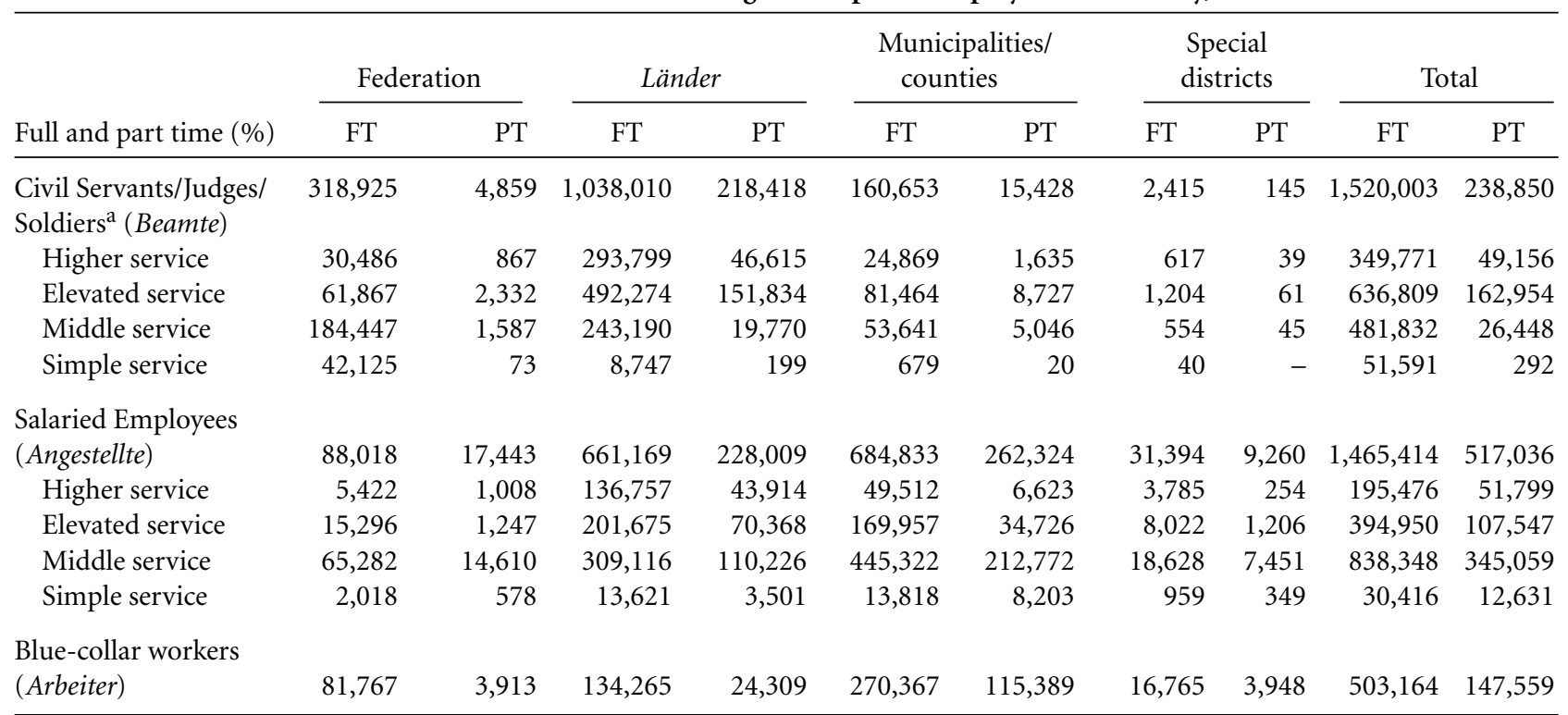

Note: ${ }^{a}$ Career and longer-serving soldiers only.

Source: Based on Federal Statistical Office, Statistical Yearbook 2000 (Stuttgart: Metzler-Poeschel, 2000), p. 517. 
requirements for the simple service levels, but previous training in an apprenticeship (Lehre) in a practical subject may be an expectation. Continuing education courses are increasingly common, especially in the first two categories. ${ }^{150}$ There is little opportunity for promotion without having met the educational requirements, regardless of the quality of performance on the job - although this has changed somewhat in recent decades. This is not much different from the private sector, where "certification" is also very important in determining opportunities for advancement. It is one reason for the enormous increase in student numbers in Germany since the late 1960s. Since the numbers of university graduates has multiplied, there are far more applicants than available positions in the higher service, so that graduates have moved into the elevated and even the middle levels since the 1970s. By the 1980s a trend could be seen toward an increase in the numbers of the two higher levels, while the middle level stagnated and the lower level was declining. Only then were efforts undertaken to place more limits on the previously generous promotion policies within the top two levels. ${ }^{151}$

On the other hand the proportions of civil servants, salaried employees, and workers have been relatively constant over the past decades if one counts the blue-collar workers in the federal railway and postal services before they were privatized in the mid-1990s. Both civil servants and salaried employees can be in the higher, elevated, and middle services. For example, police employees, firemen, and even locomotive engineers are civil servants, as are teachers, professors and bureaucrats in higher administrative positions; however, these civil servants vary in status and pay by level of service.

The Basic Law divides the authority for regulating civil servants and the other public employees between the federation and the Länder. If in the federal service, civil servants are regulated by federal law; otherwise, the federation has only framework powers under Article 75, para. 1. In 1971 the Basic Law was amended (Article 74a) to permit the federal government to pass legislation regulating the pay and benefits of all civil servants. This was done with the approval of the Länder in the Bundesrat, because they were interested in reducing the salary competition that had emerged among the Länder in spite of the federal civil service framework law of 1957 which left the Land parliaments little leeway in regulating their civil servants. ${ }^{152}$ This action is cited often as an example of the Länder giving up voluntarily certain important powers that they once possessed.

There has been considerable discussion during the past decades and again today about the rationale for preserving the difference between 
civil servants and salaried employees. ${ }^{153}$ Some politicians and others, especially on the left of the political spectrum, would like to change the status of certain classes of Beamten to Angestellten. ${ }^{154}$ Others defend the current system and for a variety of reasons are strongly opposed to any basic changes. ${ }^{155}$ Owing to their exercise of "autonomous public functions" (hoheitsrechtlicher Befugnisse), the civil servants are said to have certain characteristics that, taken together, distinguish them from other public servants:

- The civil servants have no right to strike, which is important in times of crisis. Civil servants may be called upon to substitute for personnel in the other levels if and when they go on strike.

- The civil servants, owing to their positions of trust, must not demonstrate any disloyalty to the constitutional order.

- Civil servants are life-time public servants, whose career status provides them with independence; this does not exclude probationary periods to determine suitability for office. Temporary positions also exist, but they are of questionable legality or appropriateness.

- Civil servants may be expected to work overtime and must observe certain rules of behavior in their private lives. ${ }^{156}$

\section{Loyalty expectations}

Today the second characteristic noted above is much less relevant than before the collapse of communism in East Germany and throughout eastern Europe. Loyalty expectations have always existed in the German civil service as they have in other countries, but during the Weimar Republic of 1919-33 the democratic state was confronted by many civil servants who were not loyal to the Constitution. As a result the Basic Law specifies in Article 5, para. 3, that while "art and science, research and teaching are free," the "freedom to teach does not release one from loyalty to the constitution." And Article 33, paras 4 and 5, have been interpreted to mean that those who enter the civil service must be loyal to the Federal Republic. Thus federal laws regulating the civil service have stated that only persons may become civil servants "who can be depended upon at all times to stand up for the free, democratic basic order in terms of the Basic Law." Although there was some controversy after the establishment of the Federal Republic concerning the employment of persons alleged to have served the Nazis, ${ }^{157}$ it was not until the late 1960s and early 1970 s that these provisions became an important public issue. It was then that 
student radicals, heavily influenced by Marxist thought, began to threaten to "march through the institutions" of the Federal Republic and bring about some form of revolutionary change. To keep extremists from the right and - especially - left from entering the civil service, Chancellor Willy Brandt and the prime ministers of the Länder agreed in 1972-73 to a set of principles that called for a review by the Land offices of constitutional protection of every applicant for a civil service position, including teachers. These procedures caused a great deal of controversy among the attentive public and politicians at the federal and Land levels, criticism from abroad, ${ }^{158}$ and massive opposition by students, very few of whom were actually rejected. ${ }^{159}$ By the time the Wall fell in November 1989, some of the Länder governed by the SPD had ceased participating in the reviews entirely or in part. ${ }^{160}$ Since the collapse of communism in the East, the reviews have been dropped and the issue practically forgotten. It is not surprising, then, that new questions have been raised about maintaining the differences between civil servants and salaried employees.

\section{Political patronage}

Another controversy of much longer duration and relevance today is political patronage. The model civil servant is often seen as the competent, loyal, and allegedly neutral Prussian bureaucrat in the nineteenth century and before the First World War. It has been pointed out, however, that civil servants at that time were recruited with a strong bias toward social class and conservative, pro-monarchist sentiments. ${ }^{161}$ Complaints about party patronage in the Weimar Republic after 1919 tended to ignore the issue of loyalty of many public officials to the monarchy rather than to the new republic. 162

In the United States the Hatch Act of 1939 prevents civil servants from participating actively in partisan politics, and there is a long tradition of a nonpartisan civil service in Great Britain. This has not been the German tradition. Civil servants not only participate actively in partisan politics, they are one of the most important groups from which elected officials are recruited. (One should keep in mind that teachers and professors are also civil servants in Germany, and, as in France, a large proportion of the civil servants in German legislative assemblies at all levels are teachers.) The involvement of German public employees in politics also raises questions about the neutrality of the civil service. Since the 1950s, there have been complaints about the importance of a "party book," i.e, membership in a political party, for securing higher-level civil service as well as salaried 
employee positions in federal, Land, and local administrative structures, including local government commercial enterprises, public radio and television boards, local savings and loan associations, and, of course, city government. ${ }^{163}$ On the other hand,

[p]arty patronage in the immediate post-war years had both moral and very practical functions. It could be regarded as the best indicator of regime loyalty in bureaucratic recruitment and promotions ... [Parties] had already emerged as undisputably the most 'reliable' institutions, and membership of a party licensed by the Allies was the most tangible sign of democratic commitment. ${ }^{164}$

Some German authors have also pointed to the positive binding of the civil service to society and to democratic parties after 1945 as one reason for politicization of the bureaucracy. ${ }^{165}$

Some critics accuse the German parties of being "patronage parties" rather reminiscent of the American Tammany Hall model. ${ }^{166}$ However, there are several important differences. First, the alleged corruption in Germany is of a very different order and extent from the American model. Another difference is that there was little ideology involved in the American spoils system, whereas ideology has been an element of patronage politics in Germany. A third difference is that "the career principle was modified (not displaced) in the interests of party control" in Germany, that is, "neither side expects administrative rules to be broken solely for reasons of political pressure or expediency." 167

The Tammany Hall analogy suggests itself because there is probably more patronage at the local level than elsewhere, ${ }^{168}$ although the higher Land levels are hardly exempt. ${ }^{169}$ Evidence suggests, however, that the patronage at the federal level is modest in comparison to American practices. As Renate Mayntz has noted, "In Germany most high-level vacancies continue to be filled by career civil servants even though it is understood that political criteria can play a legitimate role in recruiting outsiders to high positions in the federal bureaucracy." 170

While there is little disagreement that party membership can be a factor in gaining higher- level civil service positions at the federal, Land, and local levels, there is disagreement about whether party patronage is really a new phenomenon, the reasons why it exists, the extent to which it exists, and whether this is so very objectionable. As noted above, the argument that the Prussian bureaucracy was strictly neutral is a myth. In contrast to the many voices condemning party patronage at the federal, Land, and especially local levels and the argument by some constitutional lawyers 
that it is unconstitutional under Article 33, ${ }^{171}$ other scholars have noted that there are good reasons for the practice. As noted above, civil servants in Germany, in contrast to their American and British counterparts, may and do participate actively in politics as members of parties, as candidates, and as elected officials. ${ }^{172}$ Defenders also point out that while there may be some abuses, civil servants have an advantage in information and knowledge that can make it difficult for elected politicians to control them. To compensate for this advantage, politicians seek to gain control over the bureaucracy by insuring that persons friendly to them are appointed to key positions. They also need cooperative civil servants in drafting policy initiatives in conformity with their party programs, i.e., promises made to their voters. This is in part a result of the fact that political executives in Germany do not have large personal staffs and must rely on the civil servants for help. ${ }^{173}$ Questions can also be raised about the imprecision of the concept of patronage, and it has been noted that there is little empirical evidence for many of the general complaints made about patronage. ${ }^{174}$

Where evidence does exist about federal- and Land-level patronage, it applies above all to the highest civil service levels which consist largely of so-called "political officials" (politische Beamte) who are mostly career civil servants who occupy key positions and may be forced to accept temporary retirement for political reasons; however, only a small minority of about 10 percent are actually dismissed. Another, much smaller category, consists of the parliamentary state secretaries, who are members of the Bundestag and may answer questions for their minister at question time and perform other, more political, functions. They have existed only since 1967, in contrast to the "political officials," who go back to mid-nineteenth-century Prussia. ${ }^{175}$

\section{Public sector unions}

As we saw above, civil servants, regardless of service level, are not allowed to strike due to their status under public law as persons serving the state in special positions of authority that require trust and loyalty. Salaried employees and workers may strike and have done so on several occasions since the 1950s. The significant gains made in benefits, salaries, and employment conditions for these two groups have, of course, affected the civil servants as well. The result was a steady increase in personnel costs in proportion to total public expenditures and GNP. Today personnel costs in the old Länder average around 40 percent of their budgets. With 
growing financial stress in the public sector since the 1980s, however, the real increase in salaries and benefits has been more modest. Nevertheless, the resistance of the public service unions to privatization efforts suggests that public employees are still relatively well off in comparison to the private sector, especially in terms of job security. ${ }^{176}$

Federal and state civil servants do have their own union: the German Civil Servants Federation (Deutscher Beamten Bund, DBB). The DBB may not exercise the strike weapon, but it has excellent contacts with legislators at the Land and federal levels, many of whom are themselves former civil servants, e.g., school teachers, university employees, judges, police, various bureaucratic staff, etc., and have the right to return to their old positions if they give up their seats for whatever reason. This represents a striking difference to the United States, where civil servants are not allowed to engage openly in partisan politics or hold public office. Of course some civil servants in Germany would not be considered to be part of the civil service in the United States, e.g., school teachers and university employees.

The salaried employees (Angestellten) are represented by the German Salaried Employees Union (Deutscher Angestellten Gewerkschaft, DAG)or by several unions organized in the Federation of German Unions, i.e., the Public Transportation Union (Öffentliche Transport und Verkehr, ÖTV); the postal union; the railway workers union; or one of several competing teachers' unions, the Union for Education and Science. In 1961 the DAG and ÖTV negotiated the Federal Salaried Employees Compensation Contract (BAT) with the federal government, the Joint Salary Commission of the German Länder, and the Association of Local Government Employers.

This contract, which still generally applies today, set salary schedules and provided for various benefits that closed considerably the gap between salaried employees and civil servants. For example, civil servants can be relieved of their positions only for cause, and according to this contract the same protection applies to salaried employees after fifteen years. ${ }^{177}$ In July 2001 the largest union in the world, the united services union, or "ver.di", was formed by joining five separate unions: the DAG; ÖTV; the Union for Commerce, Banks, and Insurance; the postal union; and the media union. ${ }^{178}$

In addition to traditional union representation, civil servants and salaried employees also have the right to elect representatives to the "personnel councils" (Personalräte) of their agencies or offices which are comparable to the "works councils"(Betriebsräte) in the private sector that were introduced by a federal "codetermination" (Mitbestimmung) law in the coal and steel industry in the 1950s. These councils are important 
bodies, because they must be consulted by management in all personnel matters. This, of course, places certain constraints on the ability of managers in the public and private sectors to make personnel decisions, but the experience in most cases seems to be that relationships are based more on cooperation rather than confrontation.

\section{Conclusion}

The "state" in Germany is either the federation or the Land, depending on the context in which the term is used. Either can administer policies directly. For example, the federal government is involved in administration directly and "on its own" through a number of special agencies, such as the Federal Statistical Office and the Federal Criminal Investigation Office. It shares with the Länder the direct administration of finances. The Länder also have direct "own" administration through their special agencies, such as criminal investigation offices, statistical offices, and finance offices along with many others that fall under the direct authority of a Land ministry. Either state may also delegate policies to different bodies for indirect administration. Thus the federal government has the Länder administer the autobahns and numerous other federal tasks; but the federal government also turns over to the Länder many more tasks that they then administer on their own responsibility, not merely as delegated federal responsibilities. The Länder on their part delegate some tasks to the local governments for administration and turn over a great many other functions to the local governments for "indirect" administration on their own responsibility as self-governing units. As a result it is estimated that the local governments administer 75 percent or more of all laws in Germany. But the federation and the Länder also turn over many responsibilities to nongovernmental bodies, such as institutions, chambers, universities, and other agencies for indirect administration.

If the policy is delegated, the "state" exercises functional and personnel supervision over those actually implementing it. If the policy has been turned over to others as matters of their own responsibility, only legal supervision by higher authorities takes place. The most common example of legal supervision is that by the Länder over their local governments, which have the constitutional right of self-government.

The legal persons that administer "state" functions indirectly are various kinds of public corporations, such as local governments, social insurance providers, and numerous chambers; institutions, such as the 
public savings and loan associations and public radio and television networks; and foundations, such as those that administer certain cultural facilities or activities. ${ }^{179}$

Indirect administration can also be carried out by private persons, as, for example, by chimney sweeps and the technical inspection service (TÜV). Indirect administration works against the ideal of unity of command, but centrifugal forces are countered by many formal and informal centripetal forces. ${ }^{180}$

Even though Germany is a two-tier federation, one can speak of three levels of administration: the federal, Land, and local levels. But most of the Länder also have three levels - high, middle, and local - whereas Berlin and five of the generally smaller territorial Länder have two levels and Bremen and Hamburg have basically only one. To complicate matters further, one should note that the rural counties and their towns and villages constitute two levels, so that the larger Länder have four levels: Land, middle, county, and municipalities that constitute the counties. With the federation, this brings the total number of levels to five, unless one wants to count as separate levels the supreme and high levels, respectively, of the federation and the Länder, which is not normally done. ${ }^{181}$

In spite of the apparent complexity of administrative structures, administration in Germany is based on certain fundamental principles along with numerous exceptions that apply for mostly pragmatic reasons. The first principle is that the federal state is responsible for most legislation, the Länder for most administration. A second principle is unity of command, i.e., the attempt to combine administrative functions in one unit. At the supreme levels of the federation and the Länder, the Ministry of Interior bundles together numerous functions, while the government districts at the middle level in eight Länder serve as classic examples of unity of command. Other classic examples are the rural counties and, especially, the county-free cities. A third principle is decentralized administration based on the principle of self-government subject only to legal supervision by the state. Here the classic examples are administration by the Länder of numerous federal laws and administration by the local governments of most federal and Land laws, many of which are based on federal laws. Examples of nongovernmental institutions carrying out federal and Land laws on their own responsibility are social insurance providers and chambers. A fourth principle might be seen in the Allzuständigkeit, the general powers, of the municipalities, in contrast to the limiting principle of ultra vires in the United States; however, the general powers of the local governments have in fact been circumscribed by federal and Land 
laws. In any case it is possible to speak of a "system" of administration in federal Germany - as in unitary France - to a much greater extent than in the United States.

\section{Notes}

1 A friend of UK Prime Minister Attlee's, Professor William A. Robson (Political Quarterly 16, 1945), asserted that traditional German local government had a number of undemocratic features and therefore needed radical reform. The result of his criticism was the North German Council form of local government with city and county managers appointed by the local elected councils after the manner of the English chief clerk. It is not a little ironic that this system was largely abandoned in the mid-1990s, because it was not deemed sufficiently democratic by German critics. See Georg-Christoph von Unruh, "Die Lage der deutschen Verwaltung zwischen 1945 und 1949," in Deutsche Verwaltungsgeschichte, vol. 5, edited by Kurt G. A. Jeserich, Hans Pohl, and Georg Christian von Unruh (Stuttgart: Deutsche Verlags-Anstalt, 1987), p. 79. See also Wolfgang Rudzio, Die Neuordnung des Kommunalwesens in der Britischen Zone (Stuttgart: Deutsche Verlag Anstalt, 1968), pp. 43-45 and Arthur B. Gunlicks, Local Government in the German Federal System (Chapel Hill: Duke University Press, 1986), p. 28.

2 Rainer Wahl, "Die Organisation und Entwicklung der Verwaltung in den Ländern und in Berlin," in Jeserich et al., Deutsche Verwaltungsgeschichte, vol. 5, p. 216.

3 Potsdam Agreement, sec. 2, para. 9.

4 Wahl, "Die Organisation und Entwicklung," p. 217.

5 In the nineteenth century the Landrat was the appointed chief administrative officer of the Prussian county. See Herbert Jacob, German Administration since Bismarck: Central Authority versus Local Autonomy (New Haven: Yale University Press, 1963), pp. 15-16.

6 Von Unruh, "Die Lage," p. 71.

7 Gunlicks, Local Government, Ch. 4, and, by the same author, "The Reorganization of Local Governments in the Federal Republic of Germany," in Local Government Reform and Reorganization: An International Perspective, edited by Arthur B. Gunlicks (Port Washington: Kennikat Press, 1981), pp. 169181. In the same publication, see also Raymond C. McDermott, "The Functions of Local Levels of Government in West Germany and their Internal Organization" in ibid., pp. 182-201.

8 Wahl, "Die Organisation und Entwicklung," p. 217.

9 Ibid., p. 213.

10 Lerche in Theodor Maunz et al., Kommentar zum Grundgesetz (München: C.H. Beck'sche Verlagsbuchhandlung, 1989), Article 83, Rdnr 14. 
11 Albert von Mutius, "Kommunalverwaltung und Kommunalpolitik," in Jeserich et al., Deutsche Verwaltungsgeschichte, vol. V, pp. 328-329.

12 Ibid., p. 329.

13 Hartmut Maurer, Allgemeines Verwaltungsrecht (12th edn; München: C. H. Beck'sche Verlagsbuchhandlung, 1999), p. 543.

14 Ibid.

15 Walter Rudolf, "Verwaltungsorganisation," in Allgemeines Verwaltungsrecht, edited by Hans-Uwe Erichsen (10th edn; Berlin and New York: Walter de Gruyter, 1995), pp. 722-723.

16 Maurer, Allgemeines Verwaltungsrecht, p. 544.

17 Ibid., p. 544 and Rudolf, "Verwaltungsorganisation," pp. 722-723.

18 Rudolf, "Verwaltungsorganisation," pp. 723-724.

19 Fred Schneider, "Das Bundesversicherungsamt und seine Aufgaben," Die Sozialgerichtsbarkeit 43, no. 2 (February 1996), pp. 45-48.

20 Rudolf, "Verwaltungsorganisation," pp. 723-726.

21 These privatizations were, in German terms, organizational, not material, i.e., the federal government became the only stockholder. Short-distance routes of the German railroads have already been divided into regions, with local governments as owners, while the long-distance trains remain for the time being under the ownership of the federal government. There are plans to transfer after 2003 all mail services except for letters up to $50 \mathrm{~g}$ to the private sector.

22 Maurer, Allgemeines Verwaltungsrecht, p. 544.

23 Ibid., p. 548.

24 Rudolf, "Verwaltungsorganisation," pp. 726-727.

25 Maurer, Allgemeines Verwaltungsrecht, p. 535-536.

26 Ibid., p. 545.

27 Willi Blümel, "Verwaltungszuständigkeit," in Handbuch des Staatsrechts der Bundesrepublik Deutschland, edited by Josef Isensee and Paul Kirchhof, vol. IV, pp. 935-938.

28 Maurer, Allgemeines Verwaltungsrecht, p. 546.

29 Ibid., pp. 548-549.

30 Rudolf, Verwaltungsorganisation,” p. 727.

31 Alfred Katz, Politische Verwaltungsführung in den Bundesländern (Berlin: Duncker \& Humblot, 1975), p. 94.

32 For a discussion of the coordination activities of the prime ministers' staffs, see Klaus-Eckart Gebauer, "Zur Optimierung von Koordination und Planung in einer Regierungszentrale,” Verwaltungs-Archiv 85, no. 4 (1 October 1994), pp. 485-506.

33 Wahl, "Die Organisation und Entwicklung," p. 226.

34 Gebauer, “Zur Optimierung," pp. 507-519.

35 Manfred König, "Leistungsorganisation der Verwaltung," in Öffentliche Verwaltung in Deutschland, edited by Klaus König and Heinrich Siedentopf 
(Baden-Baden: Nomos Verlagsgesellschaft, 1996), pp. 604-605.

36 Wahl, "Die Organisation und Entwicklung," p. 223.

37 Ibid., pp. 224-225.

38 Burckhard Nedden, "Verwaltungsorganisation," in Heiko Faber and HansPeter Schneider (eds), Niedersächsiches Staats- und Verwaltungsrecht (Frankfurt/M.: Alfred Metzner Verlag, 1985), p. 124.

39 Wahl, “Die Organisation und Entwicklung," pp. 219-220.

40 Ibid., pp. 221-222.

41 Maurer, Allgemeines Verwaltungsrecht, pp. 536-537.

42 Wahl, "Die Organisation und Entwicklung," pp. 237-238.

43 Ibid., p. 228 and Theodor Elster, "Die Verwaltung," in Verfassung und Verwaltung des Landes Niedersachsen, edited by Heinrich Korte, Bernd Rebe, et al. (2nd edn; Göttingen: Vandenhoeck \& Ruprecht, 1986), p. 369.

44 Wahl, "Die Organisation und Entwicklung," pp. 228, 230.

45 Elster, “Die Verwaltung," pp. 325-327.

46 Frido Wagener, "Milderungsmöglichkeiten nachteiligen Folgen vertikaler Politikverflechtung," in Politikverflechtung im föderativen Staat, edited by Joachim Hans Hesse (Baden-Baden: Nomos Verlagsgesellschaft, 1978), pp. 149-165 and “Gemeinsame Rahmenplanung und Investitionsfinanzierung," Die Öffentliche Verwaltung 30, no. 16 (August 1977), p. 588.

47 Wahl, "Die Organisationund Entwicklung," p. 236.

48 Elster, “Die Verwaltung," pp. 369, 470-471.

49 Ibid., p. 370 and Wahl, "Die Organisation und Entwicklung," p. 229; for lists of the numerous special authorities at the district government and local levels in Lower Saxony, see Nedden, "Verwaltungsorganisation," pp. 131-133.

50 Elster, "Die Verwaltung," pp. 382-383; Wahl, "Die Organisation und Entwicklung," pp. 237-238.

51 Ibid., pp. 385-408.

52 Gesetzentwurf: Landesgesetz zur Reform und Neuorganisation der Landesverwaltung, 31 March 1999, Drucksache 13/4168 (Rheinland-Pflalz).

53 Wahl, "Die Organisation und Entwicklung," pp. 227-230.

54 Rudolf, "Verwaltungsorganisation," p. 728.

55 Wahl, "Die Organisation und Entwicklung," p. 231.

56 Elster, “Die Verwaltung," p. 371.

57 The Stadtkreis should not be confused with the Kreisstadt, which is the county seat.

58 Elster, "Die Verwaltung," pp. 424-425, 440-441.

59 Rudolf, "Verwaltungsorganisation," p. 736.

60 Maurer, Allgemeines Verwaltungsrecht, p. 539 and Rudolf, "Verwaltungsorganisation," p. 730.

61 Elster, “Die Verwaltung," pp. 372-373.

62 For a description in English of the South German Council, the Mayor, the Magistrat, and the North German Council forms of municipal government, 
see Gunlicks, Local Government, pp. 73-81; see also Maurer, Allgemeines Verwaltungsrecht, pp. 556-560 and Rudolf, "Verwaltungsorganisation," pp. 732-734; for diagrams of the forms of local government, see Bernd Becker, Öffentliche Verwaltung: Lehrbuch für Wissenschaft und Praxis (Verlag R. S. Schulz, 1989), pp. 344-350 and Joachin Jens Hesse and Thomas Ellwein, Das Regierungssystem der Bundesrepublik Deutschland, vol. 2: Materialien (7th edn; Opladen: Westdeutscher Verlag, 1992), pp. 467-470.

63 Rudolf, "Verwaltungsorganisation," p. 734 and Maurer, Allgemeines Verwaltungsrecht, pp. 558-559. Franz-Ludwig Knemeyer, "Verfassung der kommunalen Selbstverwaltung," in König and Siedentopf, Öffentliche Verwaltung in Deutschland, pp. 208 and 213, suggests that the South German Council form, now the most common in Germany, should be called the Dual Council-Mayor form.

64 Maurer, Allgemeines Verwaltungsrecht, p. 567.

65 Ibid., pp. 567-568; Elster, “Die Verwaltung,” pp. 415-416.

66 Ibid. and ibid., pp. 416-419.

67 Maurer, Allgemeines Verwaltungsrecht, pp. 571-573.

68 Ibid., pp. 539-540 and Elster, “Die Verwaltung," p. 730; Wahl, “Die Organisation und Entwicklung," p. 233.

69 Wahl, "Die Organisation und Entwicklung," p. 232.

70 Rudolf, "Verwaltungsorganisation," p. 732.

71 Ursula Münch, Sozialpolitik und Föderalismus: Zur Dynamik der Aufgabenverteilung im sozialen Bundesstaat (Opladen: Leske \& Budrich, 1997), pp. 232-246.

72 Ruland, Franz, "Sozialrecht," in Niedersächsisches Staats- und Verwaltungsrecht, edited by Heiko Faber und Hans-Peter Schneider (Frankfurt/M.: Alfred Metzner Verlag, 1985), pp. 507-508; Günter Happe, "Jugend- und Familienhilfe," in Deutsche Verwaltungsgeschichte, vol. V, pp. 596.

73 Elster, "Die Verwaltung," p. 418.

74 Rudolf, "Verwaltungsorganisation,” pp. 734-735; Maurer, Allgemeines Verwaltungsrecht, pp. 575-576.

75 Maurer, Allgemeines Verwaltungsrecht, pp. 575-576.

76 Frido Wagener and Willi Blümel, "Staatsaufbau und Verwaltungsterritorien," in König and Siedentopf, Öffentliche Verwaltung in Deutschland, pp. 118-119.

77 Wahl, "Die Organisation und Entwicklung," pp. 283-284; Reinhold Roth, "Bremen," in Handbuch der deutschen Bundesländer, edited by Falk Esche and Jürgen Hartmann (Frankfurt: Campus Verlag, 1990), p. 171.

78 Wahl, "Die Organisation und Entwicklung," pp. 289-292 and Roth, "Bremen," p. 187.

79 Peter Massing, "Berlin," in Esche and Hartmann, Handbuch der deutschen Bundesländer, p. 134 and Karsten Sommer, "Die Berliner Verwaltung nach Vereinigung, Hauptstadtbeschluß, und Verwaltungsreform," Juristische 
Rundschau, no. 10 (October 1995), p. 397.

80 Sommer, "Die Berliner Verwaltung," pp. 399-402.

81 Massing, "Berlin,” p. 148; Roth, “Bremen,” p. 185; Falk Esche and Jürgen Hartmann, "Hamburg," in Esche and Hartmann, Handbuch der deutschen Bundesländer, p. 213.

82 For a list by Land of special nonministerial organizational units, see Becker, Öffentliche Verwaltung in Deutschland, pp. 325-327.

83 Wahl, "Die Organisation und Entwicklung," pp. 237-238.

84 Ibid., pp. 239-240.

85 Walter Krebs, "Verwaltungsorganisation," Handbuch des Staatsrechts der Bundesrepublik Deutschland, vol. III, edited by Josef Isensee and Paul Kirchhof (Heidelberg: C. F. Müller Juristischer Verlag, 1988), pp. 585-587.

86 For a brief overview of social insurance administration, see Dieter Schimanke, "Selbstverwaltung außerhalb der Kommunalverwaltung, insbesondere: Selbstverwaltung in der Sozialversicherung," in König and Siedentopf, Öffentliche Verwaltung in Deutschland, pp. 257-268. For a description in English by Alfred Pfaller of "The German Welfare State After National Unification," which includes a discussion of the current fiscal crisis and alternatives, see www.armoninstitute.org/welfarestate.htm; also Christian Toft, "German Social Polic," in The Politics of Social Policy in Europe, edited by Maurice Mullard and Simon Lee (Lyme, NH: Edward Elgar Publishing, 1997), pp. 144-169. For a comprehensive description of the German welfare state, see Johannes Frerich and Martin Frey, Handbuch der Geschichte der Sozialpolitik in Deutschland, (2nd edn; München: R. Oldenbourg Verlag, 1996).

87 Elster, "Die Verwaltung," p. 521; Jochen Schmitt, “Arbeits- und Sozialversicherung einschließlich Sozialversicherung und Sozialversorgung," Deutsche Verwaltungsgeschichte, vol. 5, p. 570.

88 Martin Pfaff, "Funktionsfähiger Wettbewerb innerhalb und zwischen den gesetzlichen und privaten Krankenkassen," Arbeit und Sozialpolitik 49, no. 9/10 (1995), pp. 12-13; and Wolfgang Rüfner, "Das Gesetz zur Sicherung und Strukturverbesserung der gesetzlichen Krankenversicherung (Gesundheitsstrukturgesetz)," Neue Juristische Wochenschrift 46, no. 12 (24 March 1993), p. 756.

89 VDAK/AEV, Ausgewählte Basisdaten des Gesundheitswesens 2000 (Siegburg, 2000), p. 20.

90 Bertram Schulin (ed.), Handbuch des Sozialversicherungsrechts, vol. I, Krankenversicherungsrecht (München: C. H. Beck, 1994), pp. 1193, 1197, 1201.

91 Schmitt, “Arbeits- und Sozialversicherung," pp. 570-584; also Wolfgang Rüfner, "Daseinsvorsorge und soziale Sicherheit," in Handbuch des Staatsrechts der Bundesrepublik Deutschland, vol. III, pp. 1079-1082.

92 Günter Püttner and Bernhard Losch, "Verwaltung durch Private und in privatrechtlicher Form," in Jeserich et al., Deutsche Verwaltungsgeschichte, 
vol. V, pp. 376-77.

93 Elster, “Die Verwaltung," pp. 529-530.

94 Maurer, Allgemeines Verwaltungsrecht, pp. 577-578.

95 Klara van Eyll, "Berufständische Selbstverwaltung," in Jeserich et al., Deutsche Verwaltungsgeschichte, vol. V, pp. 355-356.

96 Ibid., pp. 358-360.

97 Ibid., pp. 362-363.

98 Franz Letzelter, "Die wissenschaftliche Hochschulen und ihre Verwaltung," in Jeserich et al., Deutsche Verfassungsgeschicte, vol. V, pp. 659-664.

99 Elster, "Die Verwaltung," pp. 509-513; Ernst Gottfried Mahrenholz, "Schulund Hochshulrecht," in Niedersächsisches Staats- und Verwaltungsrecht, pp. 540-541.

100 Much of the discussion below is based on Hermann Meyn, Massenmedien in der Bundesrepublik Deutschland (Berlin: Edition Colloquium, revised edn, 1994), pp. 117-162; see also Peter J. Humphreys, Media and Media Policy in Germany: The Press and Broadcasting since 1945 (2nd edn; Oxford/Providence: Berg, 1994). A good overview of the electronic media in Germany from the late 1940s to the late 1990s can be found in Ansgar Diller, "Öffentlich-rechtlicher Rundfunk," in Mediengeschichte der Bundesrepublik Deutschland, edited by Jürgen Wilke (Bonn: Bundeszentrale für politische Bildung, 1999), pp. 146-166.

101 Winand Gellner, "Federalism and the Controversy over the New Media in West Germany," Publius: The Journal of Federalism 19, no. 4 (Autumn 1989), pp. 133-145.

102 Humphreys, Media and Media Poicy, pp. 298-299.

103 Frankfurter Allgemeine Zeitung (16 April 1997), p. 2.

104 Diller, “Öffentlich-rechtlicher Rundfunk," pp. 153-158.

105 Hans J. Kleinsteuber and Barbara Thomass, "TV in Deutschland," Deutschland: Magazine on Politics, Culture, Business and Science, no. 2 (April 1998), pp. 24-30.

106 Klaus-Eckart Gebauer, "Interessenregelung im föderalistischen System,” in Grundrechte, soziale Ordnung und Verfassungsgerichtsbarkeit, edited by Eckart Klein (Heidelberg: C. F. Müller Juristischer Verlag, 1995), p. 75.

107 Humphreys, Media and Media Policy, pp. 140-147, 176-177, 320-321.

108 Ibid., p. 321, emphasis in the original.

109 Hesse and Ellwein, Das Regierungssystem, vol. 1, p. 140.

110 Humphreys, Media and Media Policy, pp. 255, 260, 265.

111 Kleinsteuber and Thomass, "TV in Deutschland," p. 27.

112 Ibid., pp. 27-28; German Information Center, Deutschland Nachrichten, 13 June 1997, p. 6; and Humphreys, Media and Media Policy, pp. 271-273. According to an article in the Frankfurter Allgemeine Zeitung (25 June 1999), p. 24, the public stations had 41.3 percent of the viewing public in 1998.

113 Elster, "Die Verwaltung," pp. 525-527. 
114 Mauerer, Allgemeine Verwaltungsrecht, p. 591.

115 Elster, "Die Verwaltung," pp. 534-536.

116 Ibid., pp. 538-539; Mauerer, Allgemeine Verwaltungsrecht, p. 592.

117 Püttner and Losch, "Verwaltung durch Private," vol. V, p. 374.

118 Heinrich Mäding, "Verwaltung und Planung," in Jeserich et al., Deutsche Verwaltungsgeschichte, vol. IV, pp. 1046-1047.

119 Ibid., p. 1048.

120 Ibid., p. 1049.

121 Ibid., pp. 1051-1052.

122 Mauer, Allgemeines Verwaltungsrecht, pp. 402-403.

123 Gottfried Schmitz, "Räumliche Planung," in König and Siedentopf, Öffentliche Verwaltung in Deutschland, p. 405.

124 Rainer Wahl, "Europäisches Planungsrecht Europäisierung des deutschen Planungsrechts," in Planungs-Recht-Rechtschutz, pp. 617-646.

125 Clifford Larsen, "What Should be the Leading Principles of Land Use Planning? A German Perspective," Vanderbilt Journal of Transnational Law 29, no. 5 (November 1996), pp. 967-1021.

126 Carl Sartorius, Verfassungs- und Verwaltungsgesetze der Bundesrepublik Deutschland, vol. I (München: C. H. Beck'sche Verlagsbuchhandlung, 1999), ROG 340.

127 Larsen, "What Should be ... ??" p. 981.

128 Ibid., pp. 996-1006.

129 Schmitz, "Räumliche Planung," p. 405.

130 Larsen, "What Should be ... ??" pp. 1006-1008.

131 Frido Wagener and Willi Blümel, "Staatsaufbau und Verwaltungsterritorien," in König and Siedentopf, Öffentliche Verwaltung in Deutschland, p. 119.

132 Münch, Sozialpolitik und Föderalismus, p. 149.

133 Larsen, "What Should be ... ??" pp. 993-996.

134 Münch, Sozialpolitik und Föderalismus, pp. 149-152.

135 Larsen, "What Should be ... ??" pp. 1012-1013.

136 For a detailed discussion of joint framework planning under Article 91a, see Erwin Kalinna, Die Rahmenplanung und der Rahmenplan nach Artikel 91a GG, Dissertation, University of Munich, 1985; see also Blümel, "Verwaltungszuständigkeit," pp. 952-953.

137 Bruno Schmidt-Bleibtreu and Franz Klein, Kommentar zum Grundgesetz (8th edn; Neuwied: Luchterhand Verlag, 1995), pp. 1187, 1203.

138 Ibid., pp. 1201-1202; Arthur Benz, "Verflechtung der Verwaltungsebenen," in König and Siedentopf, Öffentliche Verwaltung in Deutschland, p. 176.

139 Schmidt-Bleibtreu and Klein, Grundgesetzkommentar, Article 91a, pp. 12021204.

140 Maunz et al., Kommentar zum Grundgesetz, Article 91b, Rdnr 1-3.

141 Heinrich Mäding, "Federalism and Education Planning in the Federal Republic of Germany," Publius: The Journal of Federalism 19, no. 4 (Autumn 
1989). p. 120.

142 Ibid., p. 126.

143 Ibid., pp. 125-131; see also the discussion by Blümel, "Verwaltungszuständigkeit," pp. 954-956.

144 Blümel, "Verwaltungszuständigkeit," pp. 943, 954-956.

145 Paul Feuchte, "Die rechtliche Ordnung der Verwaltung im Bundesstaat und ihre Entwicklung," in Jeserich et al., Deutsche Verwaltungsgeschichte, vol. 5, pp. 141-142.

146 Blümel, "Verwaltungszuständigkeit," pp. 956-958.

147 Fritz W. Scharpf, “The Joint-Decision Trap: Lessons from German Federalism and European Integration," Public Administration 66 (Autumn 1988), pp. 255-271.

148 Schmidt-Bleibtreu and Klein, Grundgesetzkommentar, Article 91a, pp. 11891190; Kalinna, Die Rahmenplanung, pp. 156-159.

149 Christoph Hauschild, "Aus- und Fortbildung für den öffentlichen Dienst," in König and Siedentopf, Öffentliche Verwaltung in Deutschland, p. 581.

150 Ibid., pp. 582-589.

151 Günter Püttner, "Der öffentliche Dienst," in Jeserich et al., Deutsche Verwaltungsgeschichte, vol. 5, p. 1131; Hans Mommsen, "Wohlerworbene Rechte und Treuepflichten," in Wozu noch Beamte? Vom starren zum schlanken Berufsbeamtentum, edited by Peter Grottian (Reinbeck: Rowohlt Taschenbuch Verlag, 1996), pp. 19-36.

152 Püttner, "Der öffentliche Dienst," p. 1138.

153 Helmut Lecheler, "Der öffentliche Dienst," in Handbuch des Staatsrechts, vol. III, p. 721.

154 Heide Simonis, "Beamte oder nicht - das ist nicht die Frage," in Grottian, Wozu noch Beamte?, pp. 107-121 and also "Verwaltungsreform: Jetzt oder nie?” Verwaltung und Management 1, no. 2 (1995), pp. 68-73.

155 Detlef Merten, "Das Berufsbeamtentum als Element deutscher Rechtsstatlichkeit," in Staat und Verwaltung: Fünfzig Jahre Hochschule für Verwaltungswissenschaften Speyer, edited by Klaus Lüder (Berlin: Duncker \& Humblot, 1997), pp. 145-168.

156 Detlef Merten, "Beamtenrecht und Beamtenverfassungsrecht," in PlanungRecht-Rechtschutz, pp. 342-346, 350.

157 There was, of course, controversy in Germany over the question of civil servants who had served the Nazi regime, but there was little concern that these officials would try consciously to undermine the new democratic system after 1949.

158 For criticism by one American scholar among others, see Gerard Braunthal, Political Loyalty and Public Service in West Germany: The 1972 Decree against Radicals and its Consequences (Amherst: University of Massachusetts Press, 1990).

159 Schmidt-Bleibtreu and Klein, Grundgesetzkommentar, Article 33, p. 667. 
160 Ibid., pp. 665-673; Lecheler, “Der öffentliche Dienst,” pp. 754-756.

161 Renate Mayntz, "German Federal Bureaucrats," Bureaucrats and Policy Making: A Comparative Overview, edited by Ezra N. Suleiman (New York: Holmes \& Meier, 1984), p. 176.

162 Hans-Ulrich Derlien, "Politicization of the Civil Service in the Federal Republic of Germany: Facts and Fables," in The Politicization of Public Administration, edited by François Meyers (Brussels: International Institute of Administrative Sciences, 1985), pp. 3-4.

163 For a devastating criticism of local party patronage practices in Cologne, see Ervin K. and Ute Scheuch, Cliquen, Klüngel und Karrieren (Reinbeck: Rowohlt Taschenbuch Verlag, 1992); sharp criticisms of party patronage, particularly at the Land level, can be found in the writings of Hans Herbert von Arnim. See, for example, his Staat als Beute: Wie Politiker in eigener Sache Gesetze Machen (Munich: Knauer, 1993), Ch. 6 and Staat ohne Diener (Munich: Kindler Verlag, 1993), Ch. 4.

164 Kenneth Dyson, “The West German 'Party-Book' Administration: An Evaluation,” Public Administration Bulletin 25 (December 1977), p. 4.

165 Jörg Auf dem Hövel, "Politisierung der öffentlichen Verwaltung durch Parteien? Ursachenforschung und normative Debatte," Zeitschrift für Parlamentsfragen 27, no. 1 (January 1996), pp. 82-95; Everhard Holtmann, "Politisierung der Kommunalpolitik und Wandlungen im lokalen Parteiensystem," in Aus Politik und Zeitgeschichte B 22-23/92 (22 May 1992), p. 20.

166 "Tammany Hall” was a corrupt party "machine" that controlled New York City under "Boss Tweed" after the Civil War.

167 Dyson, “The West German 'Party-Book' Administration,” p. 20.

168 For a brief discussion in English of Filzokratie, a mixing of private and public interests in certain large cities, see Dyson, "The West German 'PartyBook' Administration,” pp. 8-12; Scheuch, Cliquen, Klüngel und Karrieren.

169 Von Arnim, Staat als Beute, Ch. 6.

170 Renate Mayntz, "The Higher Civil Service of the Federal Republic of Germany," in The Higher Civil Service in Europe and Canada, edited by Bruce L. R. Smith (Washington: The Brookings Institution, 1984), p. 65.

171 For example, Schmidt-Bleibtreu and Klein, Grundgesetzkommentar, Article 33, p. 659, and Ulrich Battis in Michael Sachs (ed.), Grundgesetz Kommentar (München: C. H. Beck'sche Verlagsbuchhandlung, 1996), p. 870, insist that party patronage in civil service appointments is unconstitutional. See also Merten, "Das Berufsbeamtentum," pp. 161-166, for a detailed analysis of constitutional and other objections.

172 Mayntz, "German Federal Bureaucrats," pp. 183-184.

173 Mayntz, “The Higher Civil Service," pp. 56-57.

174 Some empirical evidence, which is not necessarily representative of the whole and, in addition, is rather dated, can be found in Wolfgang H. Lorig, 
"Parteipolitik und öffentlicher Dienst: Personalrekrutierung und Personalpatronage in der öffentlichen Verwaltung," Zeitschrift für Parlamentsfragen 25, no. 1 (January 1994), pp. 94-107; for different meanings of patronage, see Derlien, "Politicization in the Civil Service," pp. 5-6.

175 Mayntz, “The Higher Civil Service," pp. 61-62.

176 Püttner, “Der öffentliche Dienst," p. 1134.

177 Ibid., p. 1138.

178 See the website at www.verdi.de/verdi/index.php3.

179 Burckhard Nedden, "Verwaltungsorganisation,” pp. 110-111.

180 Krebs, "Verwaltungsorganisation," pp. 578-581.

181 Wagener and Blümel, "Staatsaufbau und Verwaltungsterritorien," p. 118; Gerhard Wittkämper, "Die Landesverwaltung," in Nordrhein-Westfalen: Eine politische Landeskunde, edited by Landeszentrale für politische Bildung (Köln: W. Kohlhammer Verlag, 1984), p. 156. For a detailed description in English of the complexities of the overall administrative structures in Germany, see McDermott, “The Functions of Local Levels," pp. 182-188. 